\title{
SUMMARY OF SUSPENDED-SOLIDS CONCENTRATION DATA, CENTRAL AND SOUTH SAN FRANCISCO BAYS, CALIFORNIA, WATER YEARS 1992 AND 1993
}

By Paul A. Buchanan and David H. Schoellhamer

U.S. GEOLOGICAL SURVEY

Open-File Report 94-543

Prepared in cooperation with the SAN FRANCISCO REGIONAL WATER QUALITY CONTROL BOARD (SOUTH BAY) and the U.S. ARMY CORPS OF ENGINEERS (CENTRAL BAY) 


\title{
U.S. DEPARTMENT OF THE INTERIOR BRUCE BABBITT, Secretary
}

\author{
U.S. GEOLOGICAL SURVEY \\ GORDON P. EATON, Director
}

Any use of trade, product, or firm names in this publication is for descriptive purposes only and does not imply endorsement by the U.S. Government.

For sale by the U.S. Geological Survey

Earth Science Information Center

Open-File Reports Section

Box 25286, MS 517

Denver Federal Center

Denver, CO 80225

For additional information write to:

District Chief

U.S. Geological Survey

Federal Building, Room W-2233

2800 Cottage Way

Sacramento, CA 95825 


\section{CONTENTS}

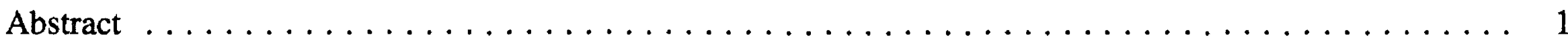

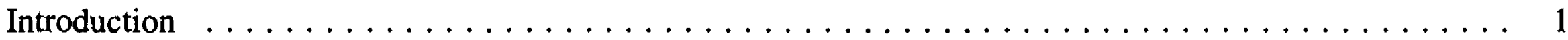

Purpose and Scope $\ldots \ldots \ldots \ldots \ldots \ldots \ldots \ldots \ldots \ldots \ldots \ldots \ldots \ldots \ldots \ldots \ldots$

Study Area $\ldots \ldots \ldots \ldots \ldots \ldots \ldots \ldots \ldots \ldots \ldots \ldots \ldots \ldots \ldots \ldots \ldots \ldots \ldots \ldots \ldots$

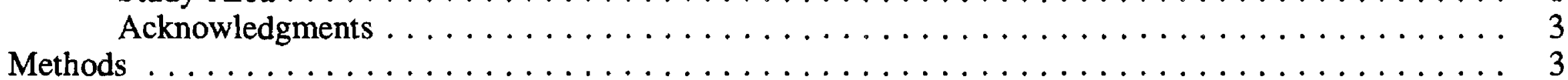

Instrument Description and Operation $\ldots \ldots \ldots \ldots \ldots \ldots \ldots \ldots \ldots \ldots \ldots$

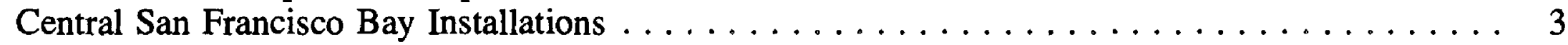

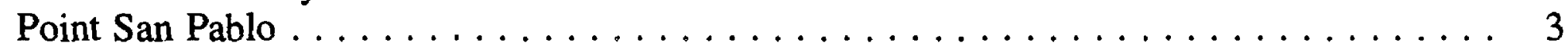

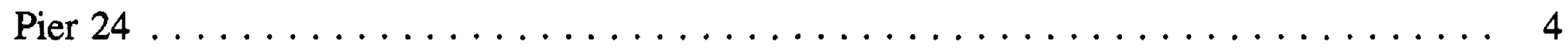

South San Francisco Bay Installations $\ldots \ldots \ldots \ldots \ldots \ldots \ldots \ldots \ldots \ldots \ldots \ldots \ldots \ldots \ldots \ldots \ldots$

Channel Marker $17 \ldots \ldots \ldots \ldots \ldots \ldots \ldots \ldots \ldots \ldots \ldots \ldots \ldots \ldots$

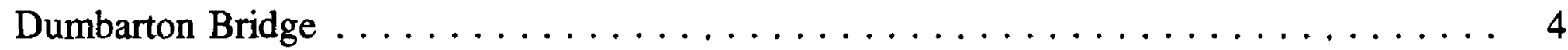

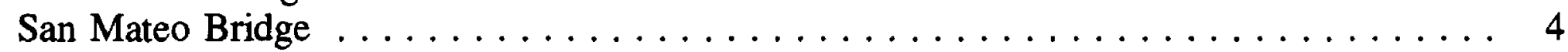

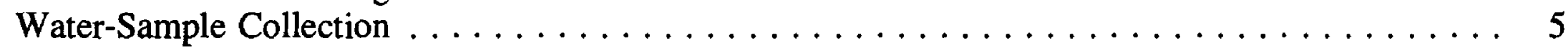

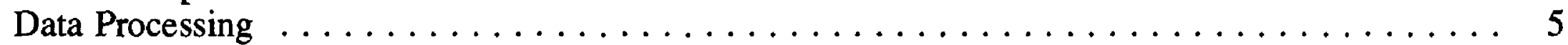

Sensor Calibration and Suspended-Solids Concentration Data for Central Bay $\ldots \ldots \ldots \ldots \ldots \ldots$

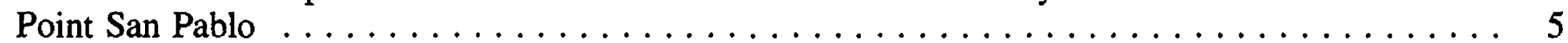

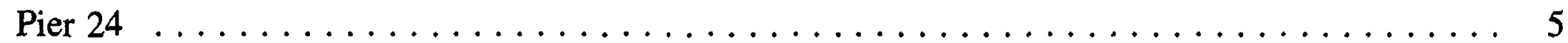

Sensor Calibration and Suspended-Solids Concentration Data for South Bay $\ldots \ldots \ldots \ldots \ldots \ldots$

Channel Marker $17 \ldots \ldots \ldots \ldots \ldots \ldots \ldots \ldots \ldots \ldots \ldots \ldots$

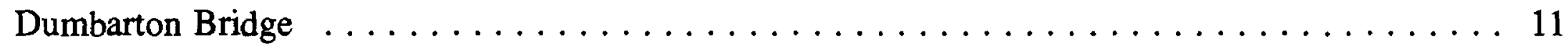

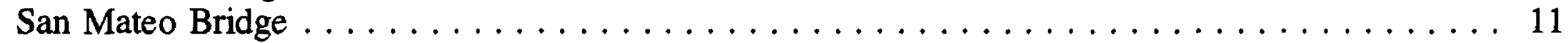

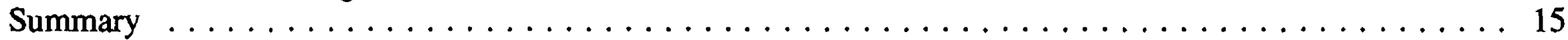

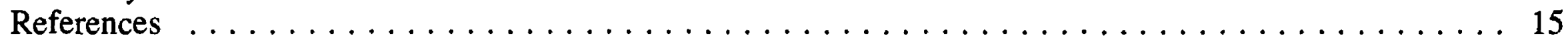

\section{FIGURES}

1. Map showing Central and South San Francisco Bays study area $\ldots \ldots \ldots \ldots \ldots \ldots$

2-22. Graphs showing:

2. Raw and edited optical backscatterance data, near-bottom sensor,

San Mateo Bridge, South Francisco Bay, California . . . . . . . . . . . . . . . 6

3. Calibration of mid-depth optical backscatterance sensor at Point San Pablo,

Central San Francisco Bay, California, water year $1993 \ldots \ldots \ldots \ldots \ldots \ldots \ldots$. . . . . . . . 6

4. Calibration of near-bottom optical backscatterance sensor at Point San Pablo,

Central San Francisco Bay, California, water year 1993 . . . . . . . . . . . . . . . . . . 6

5. Time series of mid-depth suspended-solids concentration at Point San Pablo,

Central San Francisco Bay, California, water year 1993 . . . . . . . . . . . . . . . . . .

6. Time series of near-bottom suspended-solids concentration at Point San Pablo,

Central San Francisco Bay, California, water year $1993 \ldots \ldots \ldots \ldots \ldots \ldots \ldots$. . . . . . . .

7. Calibration of mid-depth optical backscatterance sensor at Pier 24,

Central San Francisco Bay, California, water year 1993 . . . . . . . . . . . . . . . . . . .

8. Calibration of near-bottom optical backscatterance sensor at Pier 24,

Central San Francisco Bay, California, water year $1993 \ldots \ldots \ldots \ldots \ldots \ldots$

9. Time series of mid-depth suspended-solids concentration at Pier 24,

Central San Francisco Bay, California, water year $1993 \ldots \ldots \ldots \ldots \ldots$. . . . . . . . . 9

10. Time series of near-bottom suspended-solids concentration at Pier 24,

Central San Francisco Bay, California, water year 1993 . . . . . . . . . . . . . . . . .

11. Calibration of mid-depth optical backscatterance sensor at channel marker 17 ,

South San Francisco Bay, California, water years 1992 and 1993 . . . . . . . . . . 10

12. Calibration of near-bottom optical backscatterance sensor at channel marker 17 ,

South San Francisco Bay, California, water years 1992 and 1993 
13. Time series of mid-depth suspended-solids concentration at channel marker 17 ,

South San Francisco Bay, California, water years 1992 and $1993 \ldots \ldots \ldots$. . . . . . . 10

14. Time series of near-bottom suspended-solids concentration at channel marker 17 ,

South San Francisco Bay, California, water years 1992 and $1993 \ldots \ldots \ldots \ldots$. . . . . . 11

15. Calibration of mid-depth optical backscatterance sensor at Dumbarton Bridge,

South San Francisco Bay, California, water year $1993 \ldots \ldots \ldots \ldots \ldots \ldots$

16. Calibration of near-bottom optical backscatterance sensor at Dumbarton Bridge,

South San Francisco Bay, California, water year $1993 \ldots \ldots \ldots$. . . . . . . . . . . . 12

17. Time series of mid-depth suspended-solids concentration at Dumbarton Bridge,

South San Francisco Bay, California, water year $1993 \ldots \ldots \ldots \ldots \ldots \ldots \ldots \ldots$

18. Time series of near-bottom suspended-solids concentration at Dumbarton Bridge,

South San Francisco Bay, California, water year $1993 \ldots \ldots \ldots \ldots \ldots \ldots$

19. Calibration of mid-depth optical backscatterance sensor at San Mateo Bridge,

South San Francisco Bay, California, water years 1992 and 1993 . . . . . . . . . . . . 13

20. Calibration of near-bottom optical backscatterance sensor at San Mateo Bridge,

South San Francisco Bay, California, water years 1992 and 1993 . . . . . . . . . . . 13

21. Time series of mid-depth suspended-solids concentration at San Mateo Bridge,

South San Francisco Bay, California, water years 1992 and 1993 . . . . . . . . . . . 14

22. Time series of near-bottom suspended-solids concentration at San Mateo Bridge,

South San Francisco Bay, California, water years 1992 and 1993 . . . . . . . . . . . 14

\section{TABLE}

1. Statistical summary of suspended-solids concentration data, Central and South San

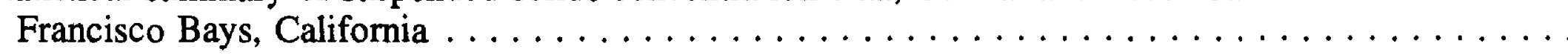

\section{CONVERSION FACTORS, ABBREVIATIONS, AND ACRONYMS}

\section{Conversion Factors}

\begin{tabular}{rcl}
\hline Multiply & By & To obtain \\
\hline foot (ft) & 0.3048 & meter \\
foot per second (ft/s) & 0.3048 & meter per second \\
inch (in.) & 25.4 & millimeter \\
pound, avoirdupois (lb) & 4.536 & kilogram \\
\hline
\end{tabular}

Temperature is given in degrees Celsius $\left({ }^{\circ} \mathrm{C}\right)$, which can be converted to degrees Fahrenheit $\left({ }^{\circ} \mathrm{F}\right)$ by the following equation:

$$
{ }^{\circ} \mathrm{F}=1.8\left({ }^{\circ} \mathrm{C}\right)+32
$$

\begin{tabular}{ll}
\multicolumn{2}{l}{ Abbreviations } \\
amp-hour & ampere per hour \\
$\mathrm{L}$ & liter \\
$\mathrm{mg} / \mathrm{L}$ & milligram per liter \\
$\mathrm{mL}$ & milliliter \\
$\mu \mathrm{m}$ & micrometer
\end{tabular}

\section{Abbreviations}

$$
\mathrm{L}
$$
$\mu \mathrm{m}$

\section{Acronyms}

AC alternating current

ADAPS automated data processing system

DC direct current

DWR California Department of Water Resources

OBS optical backscatterance

PVC polyvinyl chloride

USGS U.S. Geological Survey 


\title{
SUMMARY OF SUSPENDED-SOLIDS CONCENTRATION DATA, CENTRAL AND SOUTH SAN FRANCISCO BAYS, CALIFORNIA, WATER YEARS 1992 AND 1993
}

\author{
By Paul A. Buchanan and David H. Schoellhamer
}

\begin{abstract}
Suspended-solids concentration data were collected in Central and South San Francisco Bays during water years 1992 and 1993. Optical backscatterance sensors were used to monitor suspended solids at three sites in South San Francisco Bay and at two sites in Central San Francisco Bay. Sensors were positioned at two depths at each site, mid-depth and near-bottom. Water samples were collected periodically and were analyzed for concentrations of suspended solids. The results of the analyses were used to calibrate the electrical output of the optical backscatterance sensors. This report presents the data-collection methods used and summarizes the suspended-solids concentration data collected from December 1991 through September 1993. Calibration plots and edited data for each sensor also are presented.
\end{abstract}

\section{INTRODUCTION}

Sediments are an important component of the San Francisco Bay estuarine system. Potentially toxic substances, such as metals and pesticides, adsorb to sediment particles (Kuwabara and others, 1989; Domagalski and Kuivila, 1993). The sediments on the bottom of the bay provide the habitat for benthic communities that can ingest these substances and introduce them into the food web (Luoma and others, 1985). The bottom sediments are also a reservoir of nutrients that contribute to the maintenance of estuarine productivity (Hammond and others, 1985). The transport and fate of suspended sediment is an important factor in determining the transport and fate of the constituents adsorbed on the sediment. Suspended sediments also limit light availability in the bay, which limits photosynthesis and primary production (Cloern, 1987; Cole and Cloern, 1987), and deposit in ports and shipping channels, which require dredging (U.S. Environmental Protection Agency, 1992). The U.S. Geological Survey (USGS), in cooperation with the San Francisco Regional Water Quality Control Board (South Bay) and the U.S. Army Corps of Engineers (Central Bay), is studying the factors that affect suspended-solids concentrations in San Francisco Bay.

\section{Purpose and Scope}

This report summarizes suspended-solids concentration data collected by the USGS in Central and South San Francisco Bays in water years 1992 and 1993. Complete data are available from the files of the USGS in Sacramento. Suspended-solids concentrations were monitored at two sites in Central San Francisco Bay and at three sites in South San Francisco Bay.

\section{Study Area}

Tides in San Francisco Bay (fig. 1) are semidiurnal with a range of about $6.5 \mathrm{ft}$ at the Golden Gate and Central Bay that increases to about $10 \mathrm{ft}$ in South Bay. The tides also have a 14-day spring-neap cycle. Typical tidal currents range from $0.6 \mathrm{ft} / \mathrm{s}$ in shallow water to more than $3 \mathrm{ft} / \mathrm{s}$ in deep channels (Smith, 1987). Winds are typically strongest during the summer when there is an afternoon sea breeze. Most precipitation occurs from late fall to early spring and freshwater discharge into the bay is greatest in the spring due to snowmelt. About 90 percent of the discharge is from the Sacramento-San Joaquin River Delta, which drains the Central Valley of California (Smith, 1987). The delta discharge contains 83 to 86 percent of the fluvial sediments that enter San Fran- 


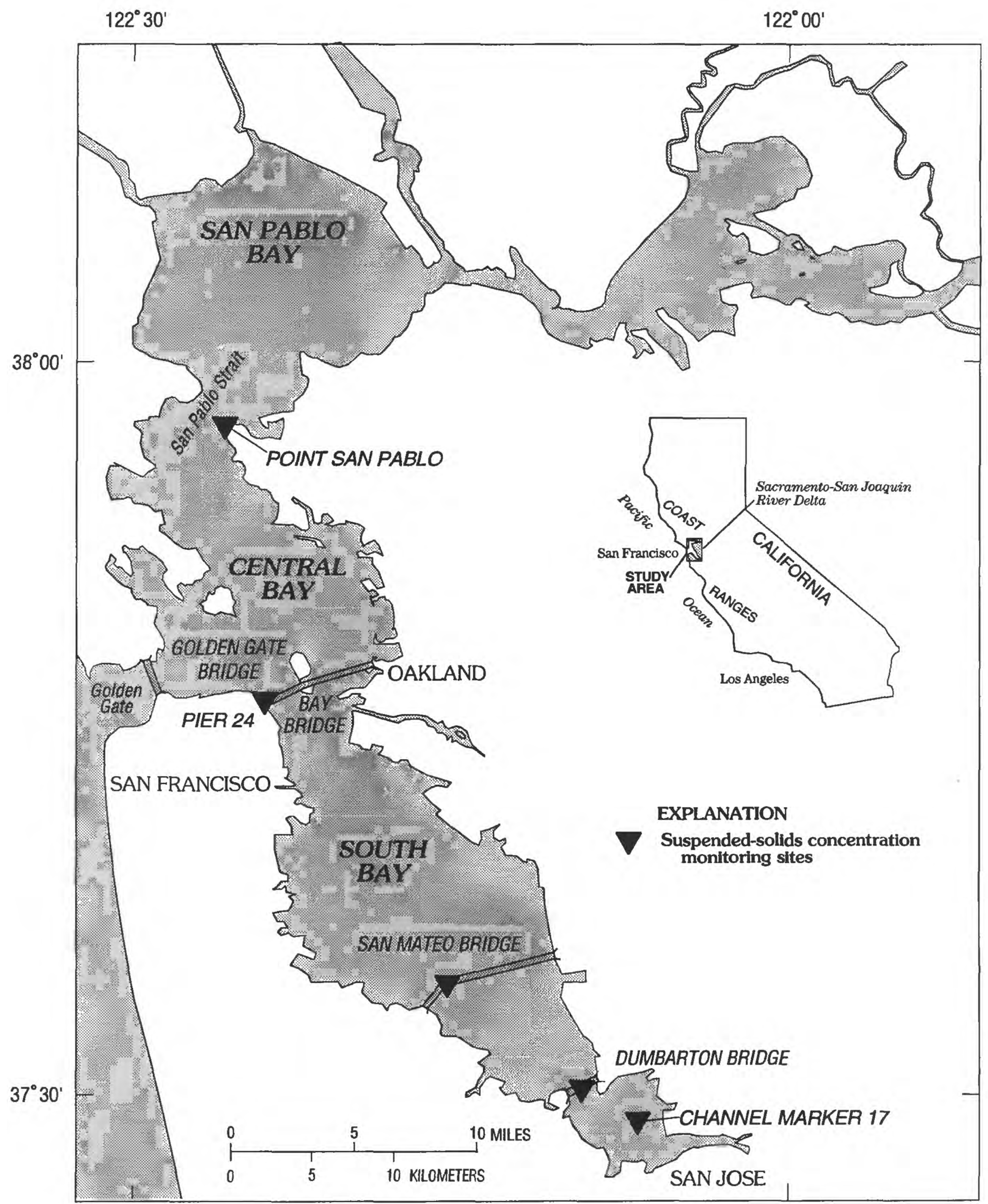

Figure 1. Central and South San Francisco Bays study area. 
cisco Bay (Porterfield, 1980). During wet winters, turbid plumes of water from the delta have extended into South Bay (Carlson and McCulloch, 1974). The bottom sediments are composed of mostly silts and clays in South Bay and in the shallow water of Central Bay (about $12 \mathrm{ft}$ or less). Silts and sands are present in the deeper parts of Central Bay (Conomos and Peterson, 1977). Large tidal velocities, spring tides, and wind waves in shallow water can resuspend bottom sediments (Powell and others, 1989).

\section{Acknowledgments}

The authors gratefully acknowledge the U.S. Coast Guard, the California Department of Transportation, the San Francisco Port Authority, and the Paktank Corporation for their permission and assistance in establishing the monitoring sites used in this study. Tom Hankins, formerly with the U.S. Geological Survey, implemented the data-collection program at the beginning of this study.

\section{METHODS}

\section{Instrument Description and Operation}

Optical backscatterance (OBS) sensors were used to monitor suspended-solids concentrations. The OBS sensor is a cylinder approximately 7 -in. long and 1 in. in diameter with an optical window at one end, a cable connection at the other end, and an encased circuit board (Downing and others, 1981; Downing, 1983). An infrared pulse of light is transmitted through the optical window and is scattered or reflected by particles in the water to a distance of about 4 to 8 in. at angles up to 165 degrees in front of the window. Some of this scattered or reflected light returns to the optical window where a receiver converts the backscattered light to a voltage output. The voltage output is proportional to the concentration of suspended solids and the turbidity in the water column. Calibration of the OBS output to concentrations of suspended solids will vary depending on the size and optical properties of the suspended solids; therefore, the OBS sensors must be calibrated either in the field or in a laboratory, using the same suspended material that is found in the field (Levesque and Schoellhamer, 1995).

The OBS sensors were positioned in the water column using polyvinyl chloride (PVC) pipe carriages that were coated with an antifoulant paint to impede biological growth. These carriages were designed to align with the direction of flow and to ride along a stainless steel or Kevlar reinforced nylon suspension line attached to an anchor weight. The sensors can be easily raised and lowered for servicing. The plane of the optical window was positioned parallel to the direction of flow, and, as the carriage and sensor aligned with the changing direction of flow, the plane of the window retained its position relative to the direction of flow.

Data acquisition, data storage, and sensor timing were controlled by an electronic data logger. The data logger was programmed to power up the OBS sensor every 15 minutes, collect data every second for 1 minute, and average and store the output voltages. Power was supplied by 12-volt DC, 12-amp-hour gel-cell batteries.

Biological growth in Central and South San Francisco Bays interferes with the collection of accurate OBS data. Frequent cleaning of OBS sensors was needed, but, because of the difficulty in servicing many of the monitoring stations, cleaning usually was done every 1 to 5 (usually 3 ) weeks. Therefore, about half of the data collected was invalidated by fouling. Fouling generally was greater on the upper OBS sensor than on the lower sensor. However, at shallower sites where the sensors were set $10 \mathrm{ft}$ apart, fouling was about equal on both sensors. Fouling would begin to affect sensor output from 2 days to several weeks after cleaning, depending on the level of biological activity in the bay. Generally, biological fouling was greatest in the spring and summer months.

\section{Central San Francisco Bay Installations}

Suspended-solids concentration data were collected at two sites in Central San Francisco Bay beginning in water year 1993: Pier 24 at San Francisco and San Pablo Strait at Point San Pablo (fig. 1).

\section{Point San Pablo}

The USGS maintains a monitoring station at San Pablo Strait on the northern end of the Port of Richmond Pier (lat. $37^{\circ} 57^{\prime} 53^{\prime \prime}$, long. $122^{\circ} 25^{\prime} 42^{\prime \prime}$ ) on the western side of Point San Pablo. The USGS took over operation of this station in October 1989 the California Department of Water Resources (DWR). Data collected prior to October 1, 1989, can be obtained from DWR. 
OBS sensors were installed at Point San Pablo on December 1, 1992, and were positioned at nearbottom and mid-depth $(3 \mathrm{ft}$ and $13 \mathrm{ft}$ from the bottom). Mean lower low water depth at this site is about $26 \mathrm{ft}$. Electrical conductance and temperature data are collected at near-top and near-bottom points in the water column. Sensor timing and storage are controlled by a data logger connected to a phone line and modem. Water level is recorded using a floatdriven, incremental encoder wired into the data logger, and outside water levels are read using a wireweight gage. A separate data logger controls the OBS sensors. AC power is available at this site and is used to charge a 12-volt, 60 -amp-hour battery that powers the data loggers and sensors. The instruments are housed in a 5 - $\mathrm{ft}$ by $8-\mathrm{ft}$ wooden shelter.

\section{Pier 24}

The monitoring station at Pier 24 is on the western end of the San Francisco-Oakland Bay Bridge (lat. $37^{\circ} 47^{\prime} 27^{\prime \prime}$, long. $122^{\circ} 23^{\prime} 05^{\prime \prime}$ ). The USGS took over operation of this station from DWR in October 1989. Data collected prior to October 1, 1989, can be obtained from DWR.

OBS sensors were installed at the Pier 24 site on May 25, 1993, and were positioned at near-bottom and mid-depth ( $3 \mathrm{ft}$ and $23 \mathrm{ft}$ above the bottom). Mean lower low water depth at this site is about 41 $\mathrm{ft}$. As at the Point San Pablo site, electrical conductance and temperature data are collected at near-top and near-bottom points in the water column. Sensor timing and storage are controlled by a data logger connected to a cellular phone and modem. AC power is available at this site and is used to charge a 12volt, 12-amp-hour battery that powers the instumentation. A corrugated steel shelter houses the equipment.

\section{South San Francisco Bay Installations}

Suspended-solids concentration data were collected at three sites in South San Francisco Bay (fig. 1). Monitoring stations were installed in water year 1992 at two sites, South San Francisco Bay at channel marker 17 and South San Francisco Bay at San Mateo Bridge. The South San Francisco Bay at Dumbarton Bridge monitoring station was installed in water year 1993.

\section{Channel Marker 17}

The southernmost monitoring site in South San Francisco Bay is at Coast Guard channel marker 17 south of the Southern Pacific Railroad swing bridge (lat. $37^{\circ} 28^{\prime} 44^{\prime \prime}$, long. $122^{\circ} 04^{\prime} 38^{\prime \prime}$ ). Instrumentation was installed on February 26, 1992, and the OBS sensors were positioned at near-bottom and mid-depth ( $3 \mathrm{ft}$ and $13 \mathrm{ft}$ from the bottom). The mean lower low water depth at this site is about $25 \mathrm{ft}$. Sensor cables are protected by a 10-ft length of PVC pipe strapped to the channel marker support column. Sensor cables, carriages, and probes are suspended in the water column using a 100-lb weight attached to a Kevlar reinforced nylon line. The data logger and DC power are housed in a $2-\mathrm{ft}$ by $2-\mathrm{ft}$ by $1-\mathrm{ft}$ weather-proof enclosure mounted on the channel marker platform.

\section{Dumbarton Bridge}

Suspended-solids concentration monitoring equipment was installed on October 21, 1992, at Pier 23 of the Dumbarton Bridge. A ship channel is east of Pier 23. OBS sensors were deployed at near-bottom and mid-depths ( $3 \mathrm{ft}$ and $23 \mathrm{ft}$ above the bottom). Mean lower low water depth at this site is about $45 \mathrm{ft}$. The OBS sensors are suspended between the concrete pier superstructure and the fender boards, an approximate distance of $3 \mathrm{ft}$. PVC carriages, attached to $1 / 4$-in. Kevlar reinforced nylon line, are anchored to a $100-1 \mathrm{~b}$ weight and are used to suspend the sensors at the desired depth. A data logger powered by two 12-volt, 12-amp-hour batteries controls sensor timing, data storage, and retrieval parameters. A weather-proof shelter mounted on the pier houses the instrumentation.

\section{San Mateo Bridge}

The monitoring station on the San Mateo Bridge is at Pier 20 on the east side of the ship channel (lat. $37^{\circ} 35^{\prime} 04^{\prime \prime}$, long. $\left.122^{\circ} 14^{\prime} 59^{\prime \prime}\right)$. This station originally was operated by DWR, but the USGS took over operations on October 1, 1989.

The OBS sensors were installed on December 23, 1991, and were positioned at near-bottom and middepth ( $3 \mathrm{ft}$ and $23 \mathrm{ft}$ above the bottom). Mean lower low water depth at this site is about $48 \mathrm{ft}$. The instruments are housed in a wooden shelter on the pier, which is surrounded by a protective fender structure. The instrument probes are deployed between the pier and the fender, and flow past the sensors is affected to some degree by turbulence created by the pilings and the concrete superstructure. Sensors are suspended in place using PVC carriages and stainless 
steel cable attached to a $200-1 b$ weight. A separate data logger and modem are used to control sensor timing, data storage, and retrieval. AC power is available at this site and all instruments are run by a 12-volt, 60-amp-hour battery with an AC/DC charger and regulator. In addition to suspended-solids concentrations, electrical conductivity and temperature are monitored at near-top and near-bottom depths.

\section{Water-Sample Collection}

Water samples were collected using a P-72 point sampler positioned at sensor depth. The P-72 is a torpedo-shaped sampler that has a solenoid that opens and closes the intake, which allows a sample to be collected at a specific depth and for a specific amount of time. A 1-L plastic bottle placed within the sampler was used to collect the water samples. A nylon nozzle with a 1/4-in. opening controls the velocity of the flow into the sampler.

Water samples were collected before and after cleaning of the sensors. With the OBS sensors deployed, the sampler was lowered to the depth of the sensor by a reel and crane assembly. The reel has conductive cable, which allows an electrical current to trigger the sampler solenoid. The sampler was kept open long enough to collect at least $200 \mathrm{~mL}$ of water, which is the minimum amount needed for analysis of suspended-solids concentration. The sample was then removed from the sampler, marked for identification, and placed in a cooler and chilled to prevent biological growth.

San Francisco Bay is a saline environment that is corrosive to the sampling equipment. The electrical components of the P-72 sampling instrument were particularly susceptible to corrosion and would often malfunction. A Van Dorn bottle was used as a backup sampler when the P-72 was inoperable. The Van Dorn bottle is a plastic tube with rubber stoppers at each end that snap shut when triggered by a small weight dropped down the suspension cable.

Samples were sent to the USGS Sediment Laboratory in Salinas, Calif., for analysis to determine suspended-solids concentration. Each sample was mixed well and a suitable volume was quickly poured off into a graduated cylinder. The suspended solids were collected on a $0.45-\mu \mathrm{m}$ membrane filter, the filter was rinsed to remove salts, and the insoluble material was dried at $103^{\circ} \mathrm{C}$ and weighed (Fishman and Friedman, 1989).

\section{Data Processing}

Data loggers stored the voltage outputs from the OBS sensors every 15 minutes. Recorded data were downloaded from the data logger onto a storage module during site visits by USGS personnel. Raw data from the storage modules were loaded into the USGS automated data processing system (ADAPS).

The time-series data were retrieved and visually edited to remove invalid data. Invalid data included rapidly increasing voltage outputs and unusually high voltage outputs of short duration. As biological growth occurred on the OBS sensors, the voltage output of the sensors increased rapidly. An example time series of raw and edited data is presented in figure 2. After the sensors were cleaned, sensor output decreased discontinuously (fig. 2, days 570 and 592). Efforts to correct the invalid data proved to be unsuccessful because the desired signal was sometimes highly variable. Thus, data collected during the period prior to sensor cleaning were often unusable and were removed from the record (fig. 2). Spikes in the OBS data, which are anomalously high voltages probably caused by debris temporarily wrapping around the sensor or by large marine organisms (fish, crabs) on or near the sensor, were also removed from the raw data record (fig. 2).

\section{SENSOR CALIBRATION AND SUSPENDED-SOLIDS CONCENTRATION DATA FOR CENTRAL BAY}

\section{Point San Pablo}

The calibration of the mid-depth sensor at Point San Pablo had a standard error of $25.9 \mathrm{mg} / \mathrm{L}$ (fig. 3), and the calibration of the near-bottom sensor had a standard error of $33.8 \mathrm{mg} / \mathrm{L}$ (fig. 4). Suspendedsolids concentration data collected during the 1993 water year are presented in figures 5 and 6 . A statistical summary is presented in table 1. Data collected by the mid-depth sensor were 79.7 percent valid, and data collected by the near-bottom sensor were 89.5 percent valid.

\section{Pier 24}

The calibration of the mid-depth sensor at Pier 24 had a standard error of $8.17 \mathrm{mg} / \mathrm{L}$ (fig. 7), and the calibration of the near-bottom sensor had a standard error of $12.6 \mathrm{mg} / \mathrm{L}$ (fig. 8). Suspended-solids concentration data collected during water year 1993 are presented in figures 9 and 10 and a statistical summary 

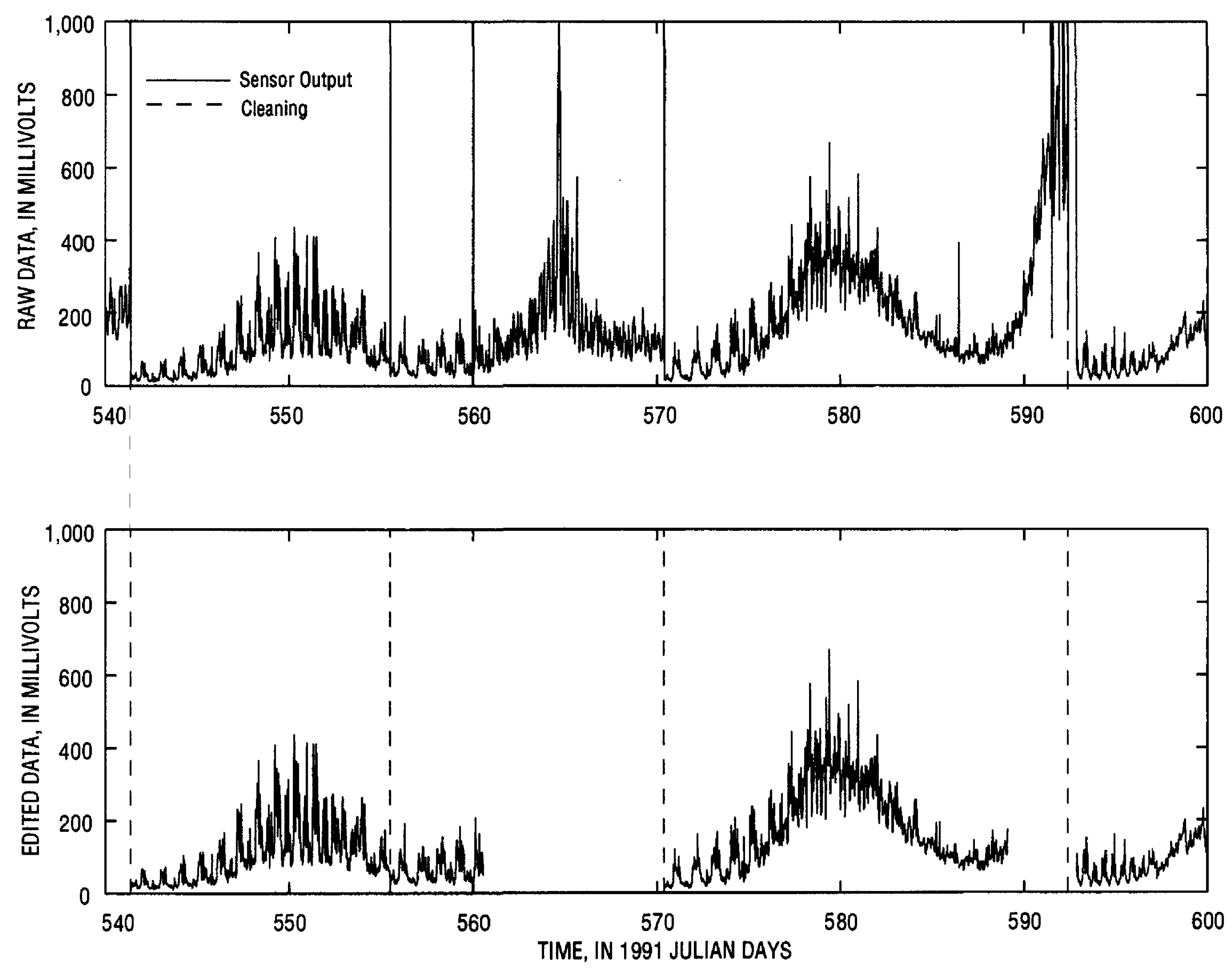

Figure 2. Raw and edited optical backscatterance data, near-bottom sensor, San Mateo Bridge, South San Francisco Bay, California.

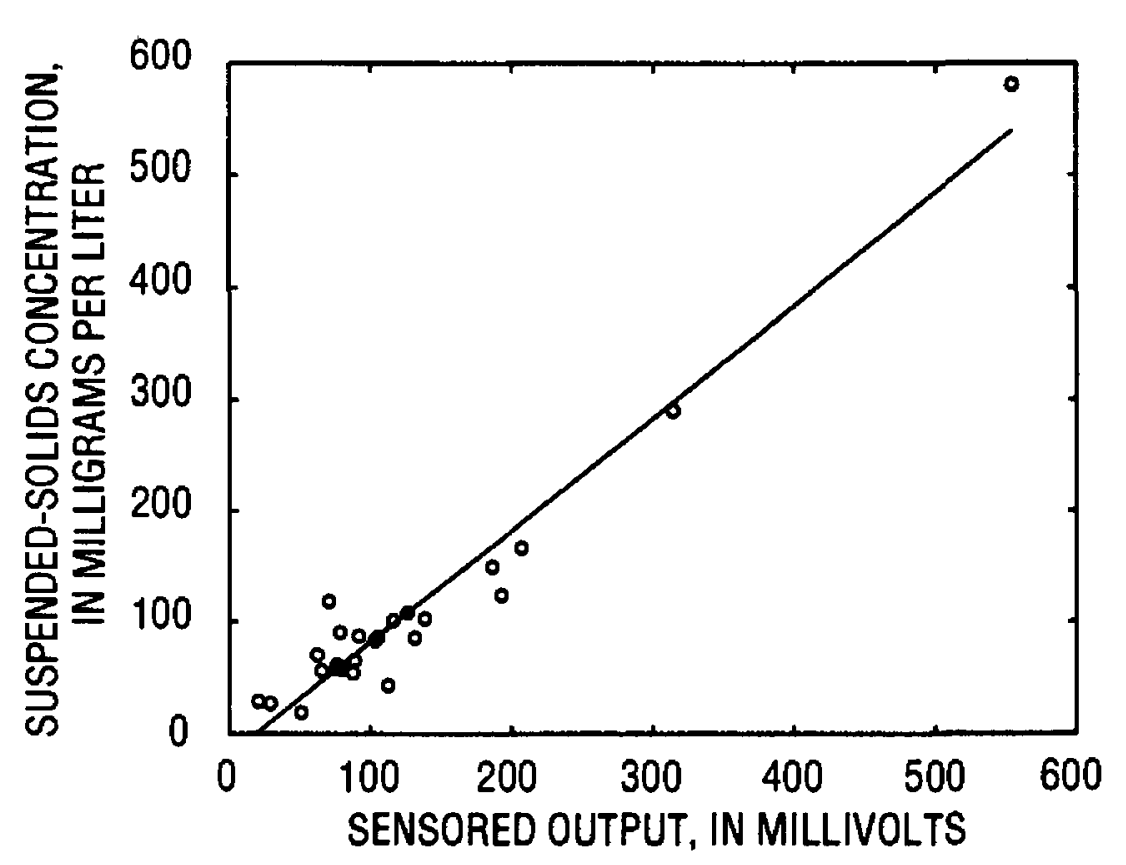

Figure 3. Calibration of mid-depth optical backscatterance sensor at Point San Pablo, Central San Francisco Bay, California, water year 1993.

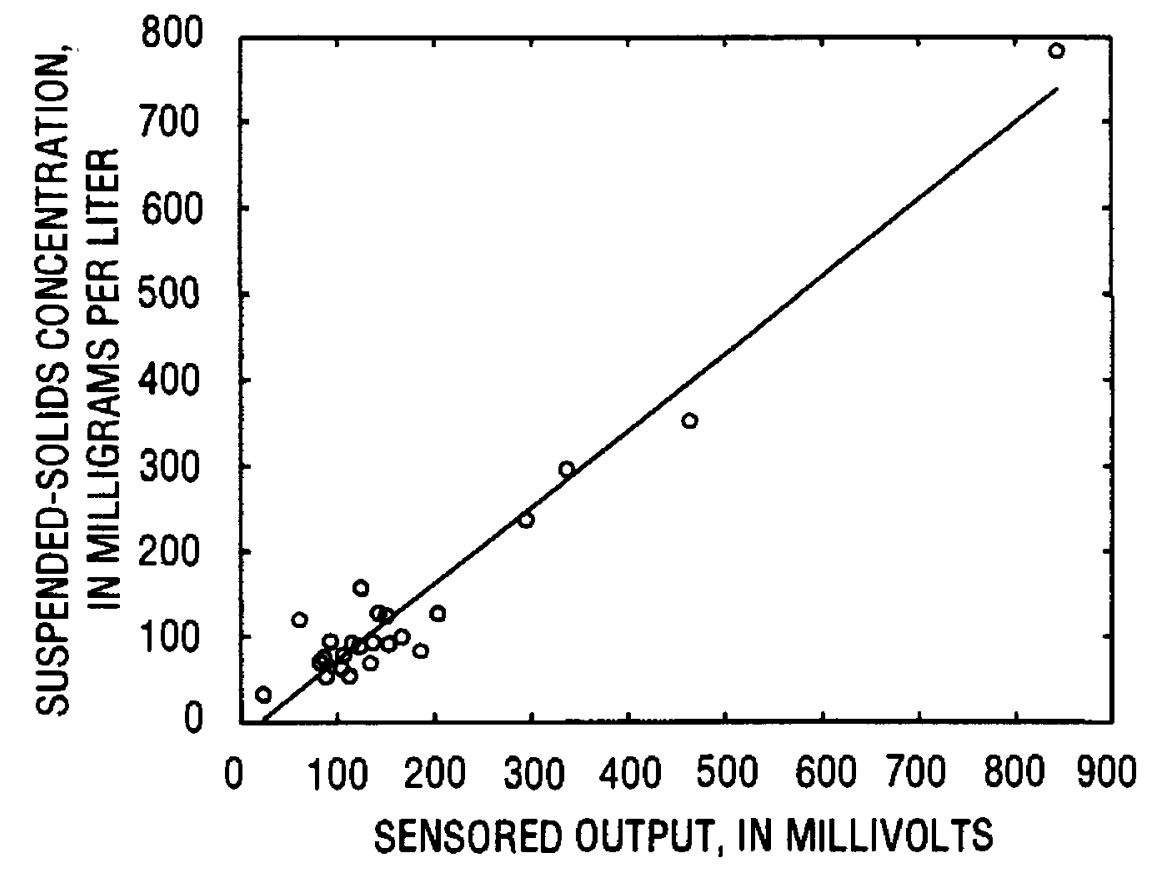

Figure 4. Calibration of near-bottom optical backscatterance sensor at Point San Pablo, Central San Francisco Bay, California, water year 1993. 


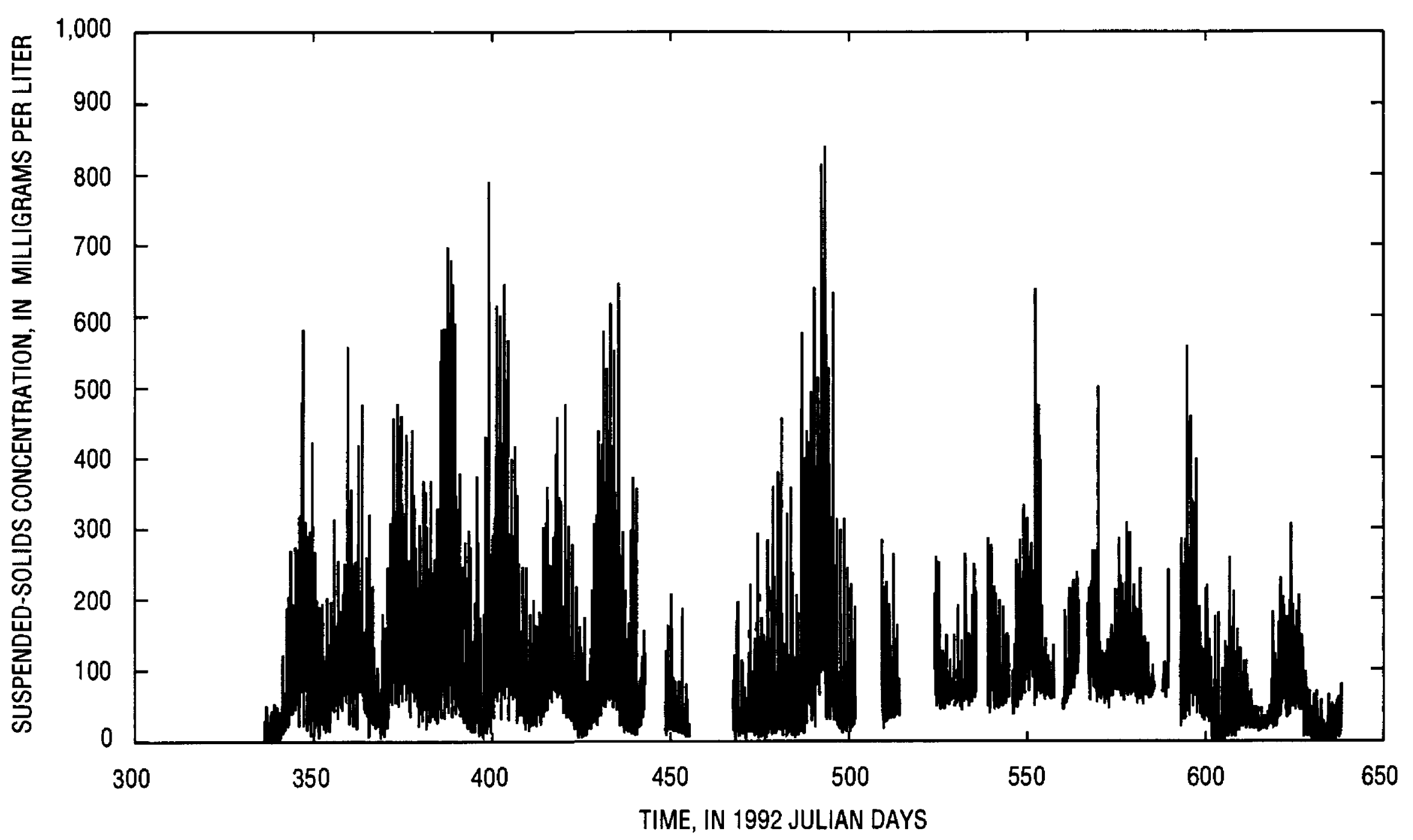

Figure 5. Time series of mid-depth suspended-solids concentration at Point San Pablo, Central San Francisco Bay, California, water year 1993.

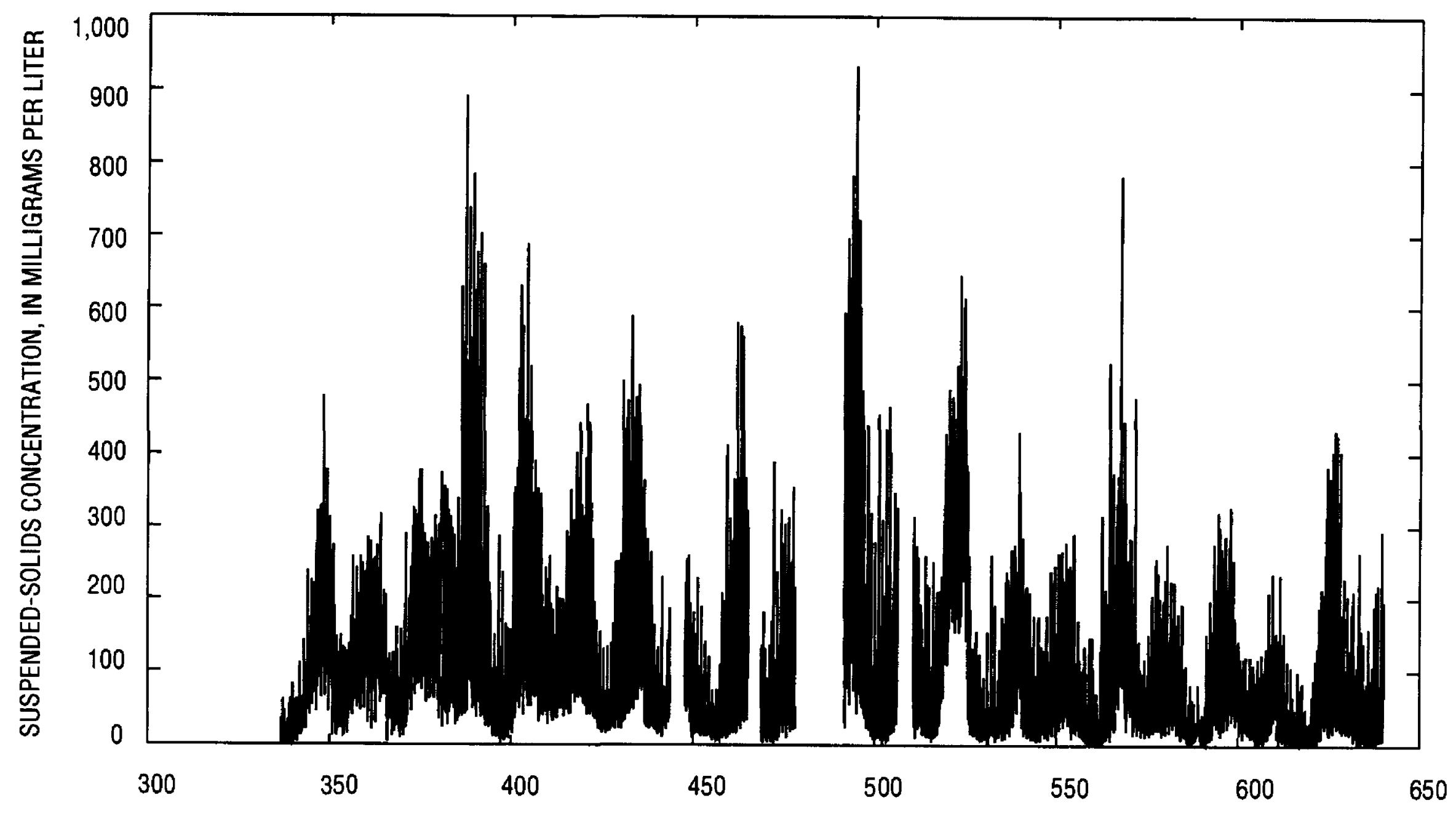

TIME, IN 1992 JULIAN DAYS

Figure 6. Time series of near-bottom suspended-solids concentration at Point San Pablo, Central San Francisco Bay, California, water year 1993. 
Table 1. Statistical summary of suspended-solids concentration data, Central and South San Francisco Bays, California

[All measurements given in milligrams per liter]

\begin{tabular}{llcccc}
\hline \multicolumn{1}{c}{ Site } & Depth & Mean & Median & Lower quartile & Upper quartile \\
\hline Point San Pablo & Mid-depth & 87.9 & 70.4 & 37.3 & 114 \\
& Near-bottom & 90.9 & 65.3 & 31.5 & 121 \\
Pier 24 & Mid-depth & 29.0 & 24.4 & 15.3 & 37.4 \\
& Near-bottom & 36.0 & 32.5 & 17.7 & 48.8 \\
Channel Marker 17 & Mid-depth & 121 & 88.6 & 52.8 & 153 \\
& Near-bottom & 170 & 108 & 67.1 & 197 \\
Dumbarton Bridge & Mid-depth & 72.9 & 64.1 & 48.8 & 86.7 \\
& Near-bottom & 93.6 & 82.2 & 56.7 & 118 \\
San Mateo Bridge & Mid-depth & 65.7 & 53.4 & 34.8 & 82.4 \\
& Near-bottom & 95.2 & 76.9 & 45.8 & 119 \\
\hline
\end{tabular}

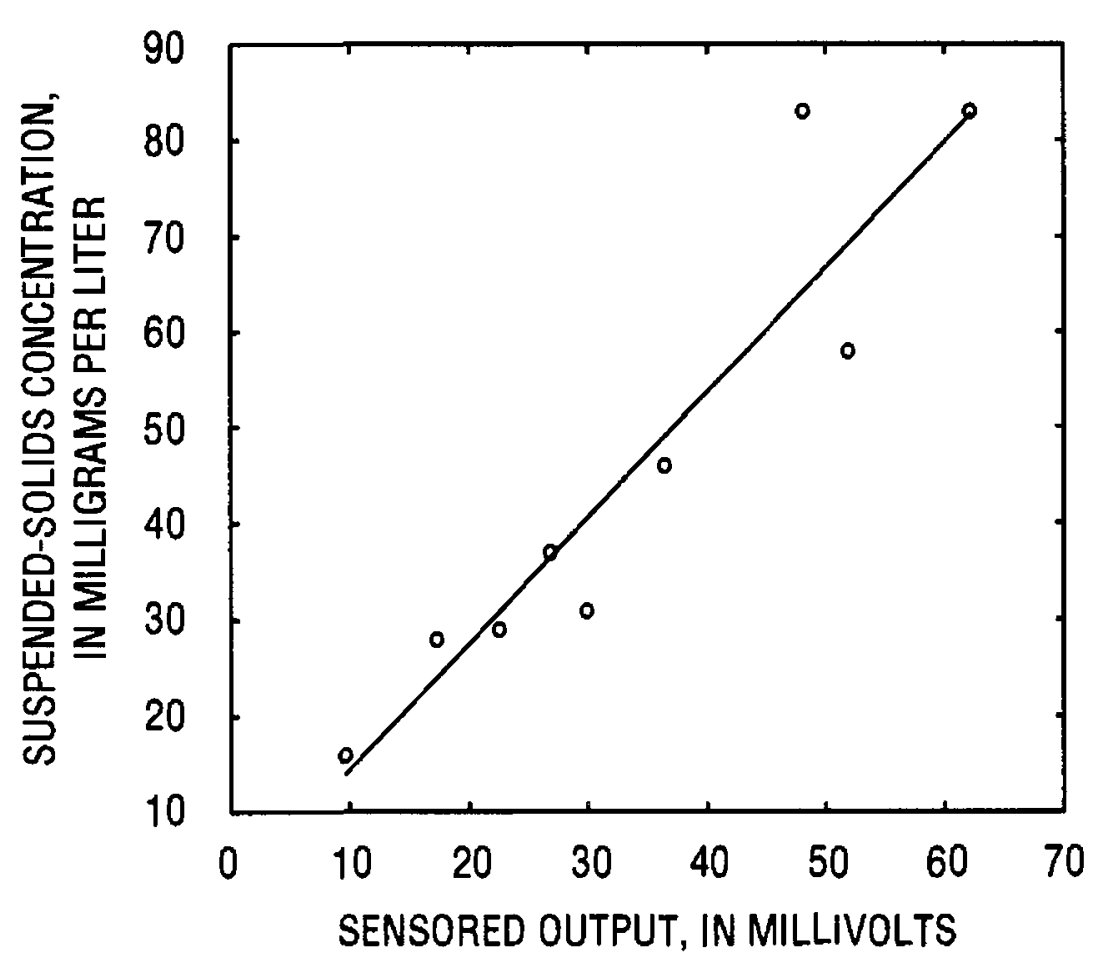

Figure 7. Calibration of mid-depth optical backscatterance sensor at Pier 24, Central San Francisco Bay, California, water year 1993.

is given in table 1 . Data collected by the mid-depth sensor were 49.8 percent valid, and data collected by the near-bottom sensor were 43.9 percent valid.

\section{SENSOR CALIBRATION AND SUSPENDED-SOLIDS CONCENTRATION DATA FOR SOUTH BAY}

\section{Channel Marker 17}

The calibration of the mid-depth sensor at channel marker 17 had a standard error of $17.6 \mathrm{mg} / \mathrm{L}$ (fig. 11). Heavy fouling, noted before cleaning on August 13,

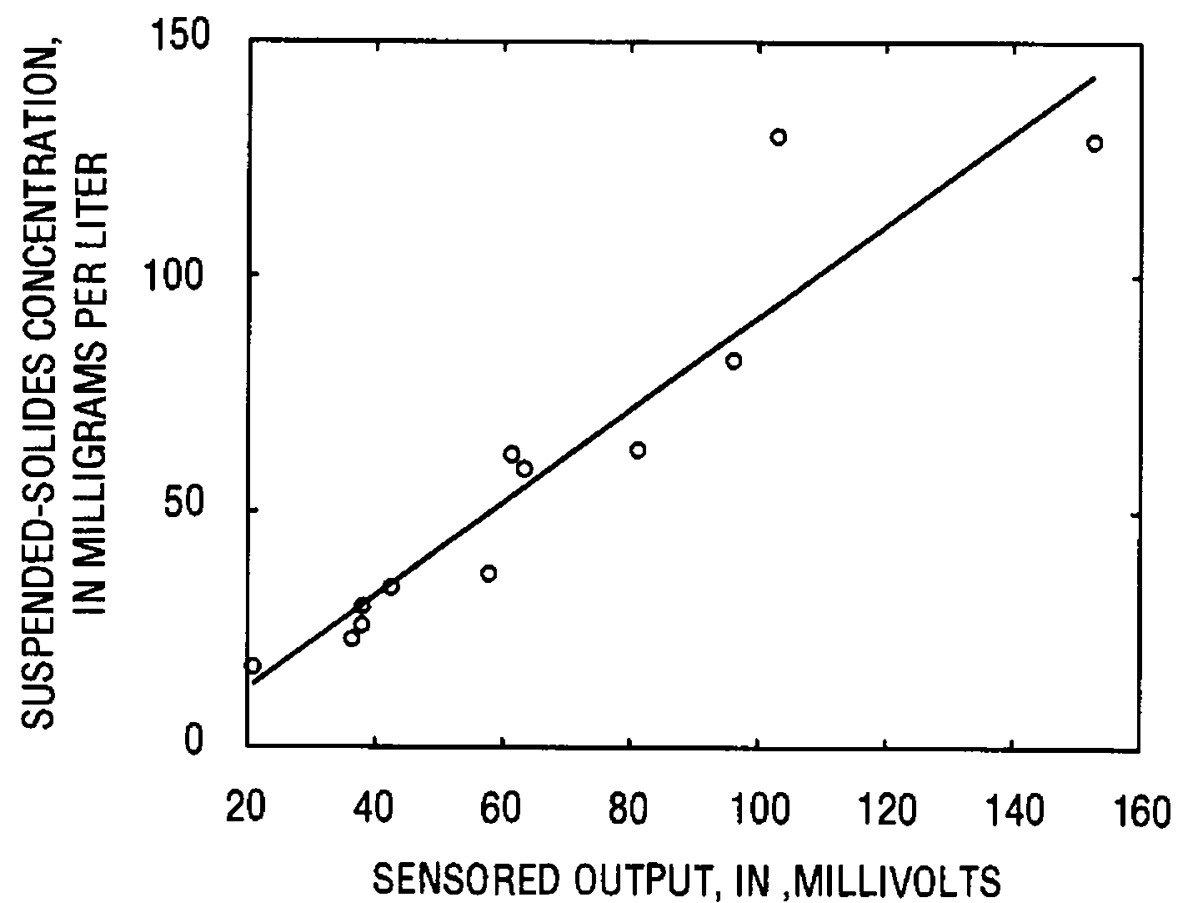

Figure 8. Calibration of near-bottom optical backscatterance sensor at Pier 24, Central San Francisco Bay, California, water year 1993.

1992 , is believed to have caused a shift in the calibration of the lower sensor. On April 13, 1993, heavy fouling again was observed on the lower sensor, and after cleaning, the sensor shifted back to its original calibration. The calibration prior to August 13, 1992, and after April 13, 1993, had a standard error of $11.5 \mathrm{mg} / \mathrm{L}$, and the calibration between August 13, 1992, and April 13, 1993, had a standard error of $18.0 \mathrm{mg} / \mathrm{L}$ (fig. 12). Suspended-solids concentration data collected during water years 1992 and 1993 are presented in figures 13 and 14 and a statistical summary is given in table 1 . Data collected by the mid-depth sensor were 56.9 percent valid, and data collected by the near-bottom sensor were 48.6 percent valid. 


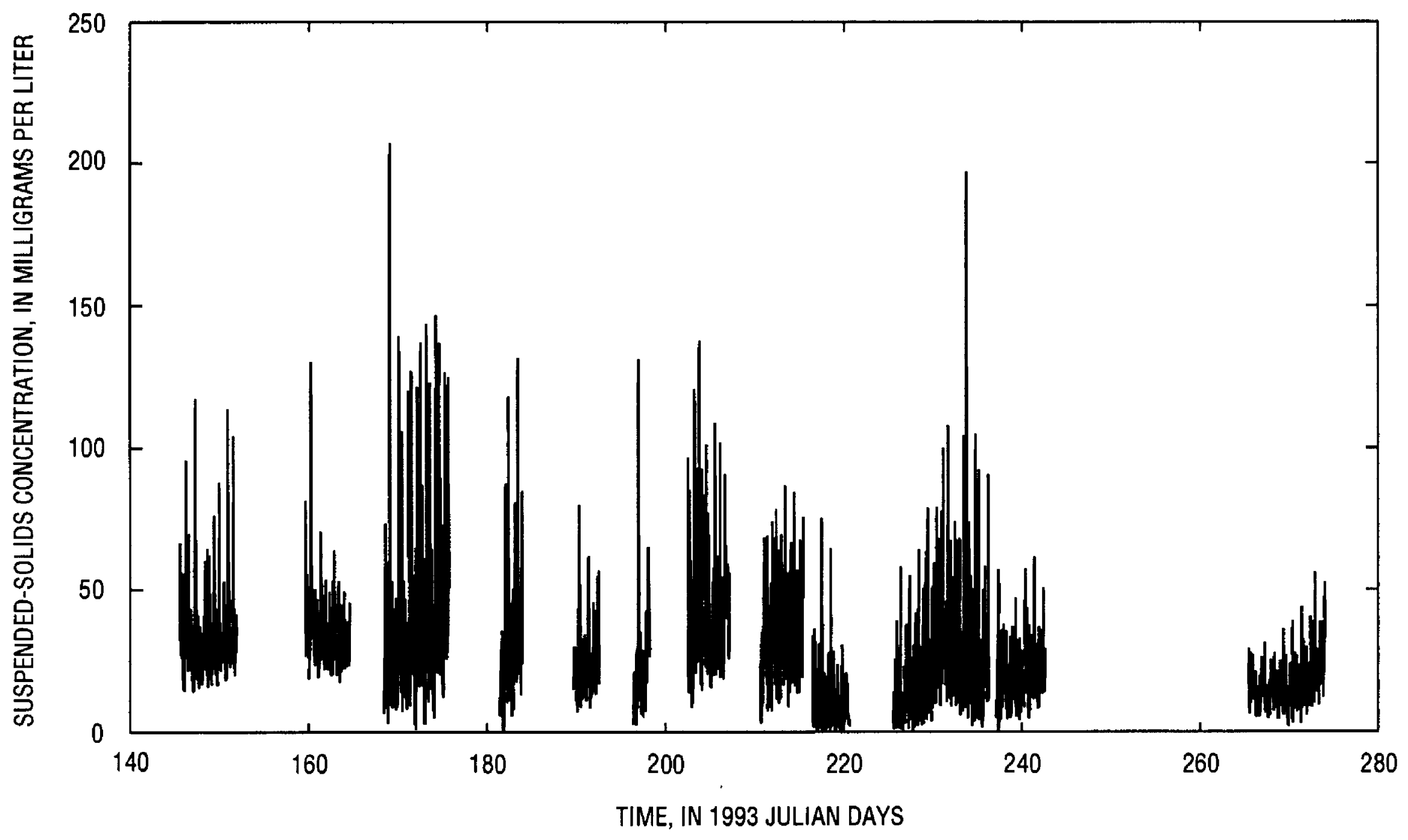

Figure 9. Time series of mid-depth suspended-solids concentration at Pier 24, Central San Francisco Bay, California, water year 1993.

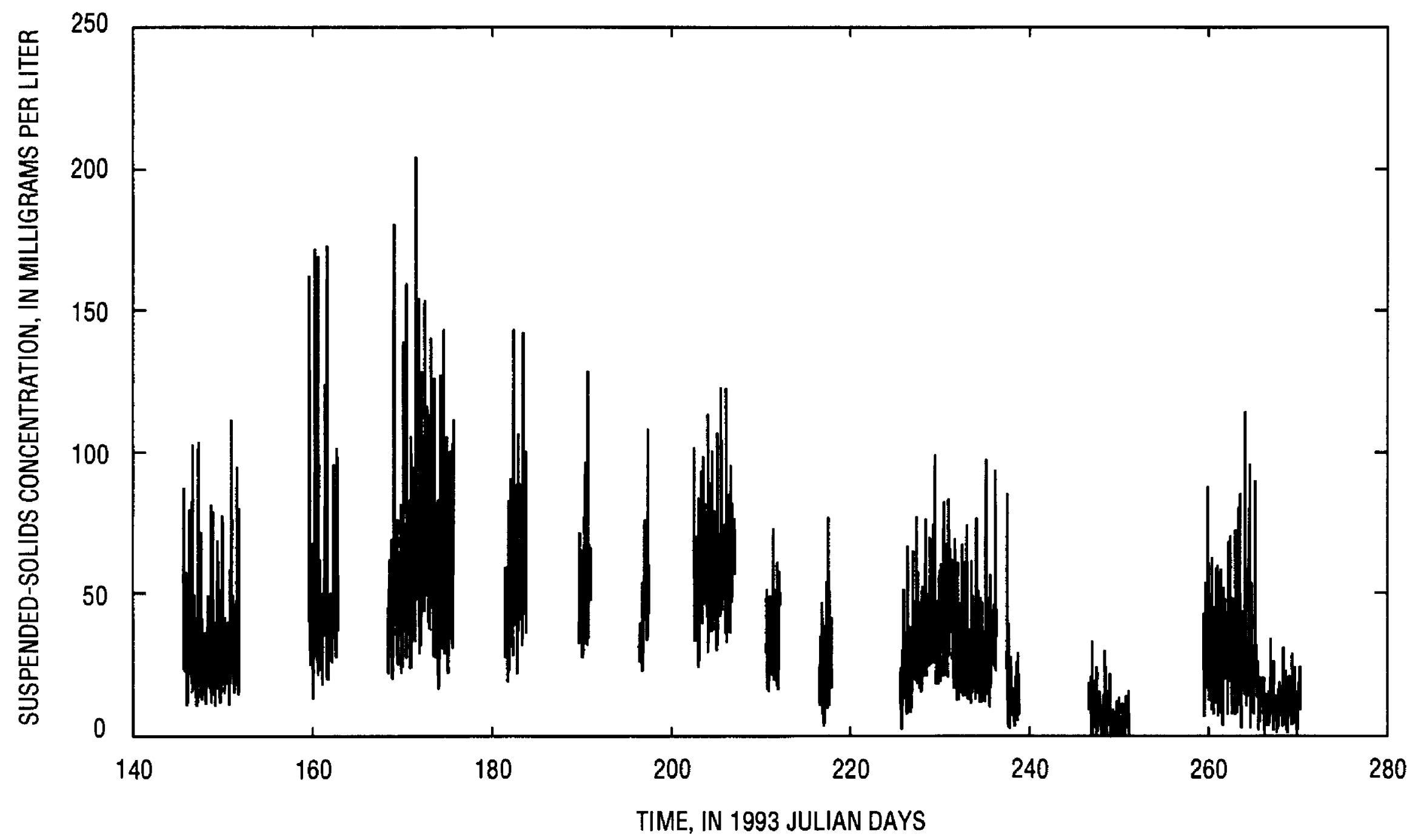

Figure 10. Time series of near-bottom suspended-solids concentration at Pier 24, Central San Francisco Bay, California, water year 1993. 


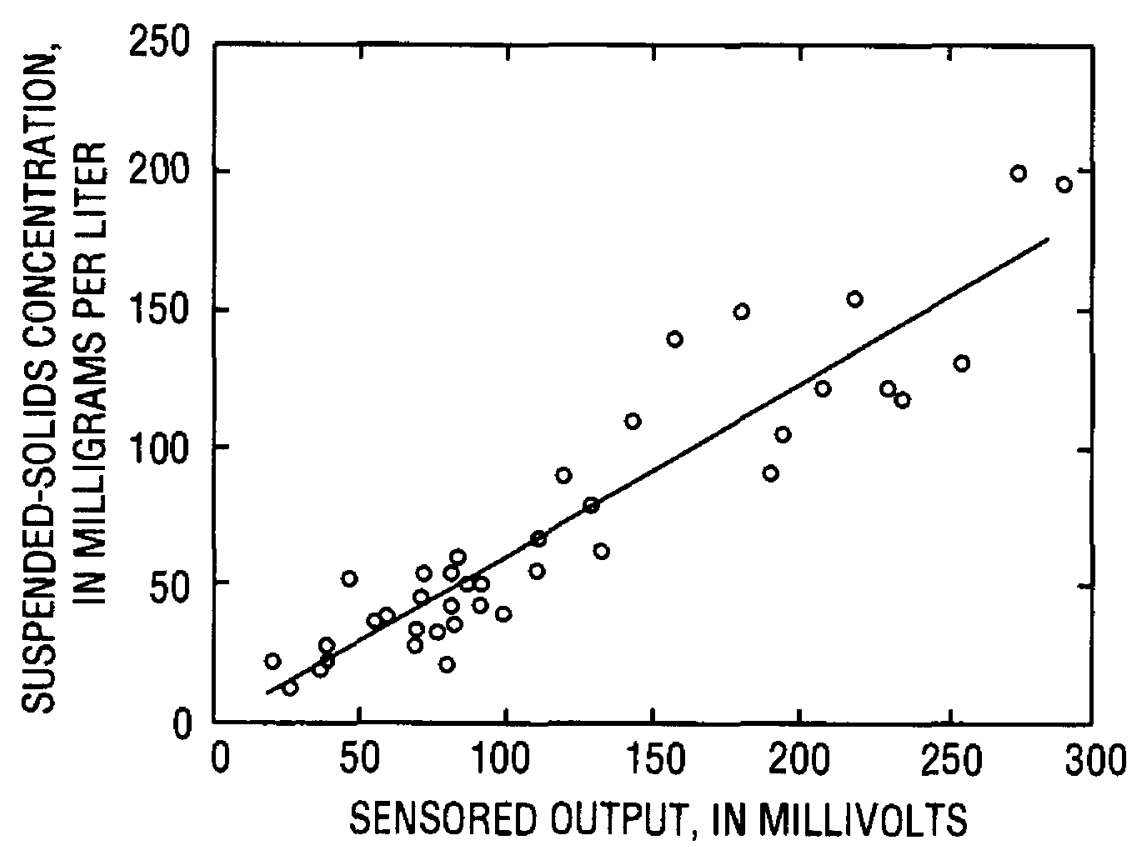

Figure 11. Calibration of mid-depth optical backscatterance sensor at channel marker 17 , South San Francisco Bay, California, water years 1992 and 1993.

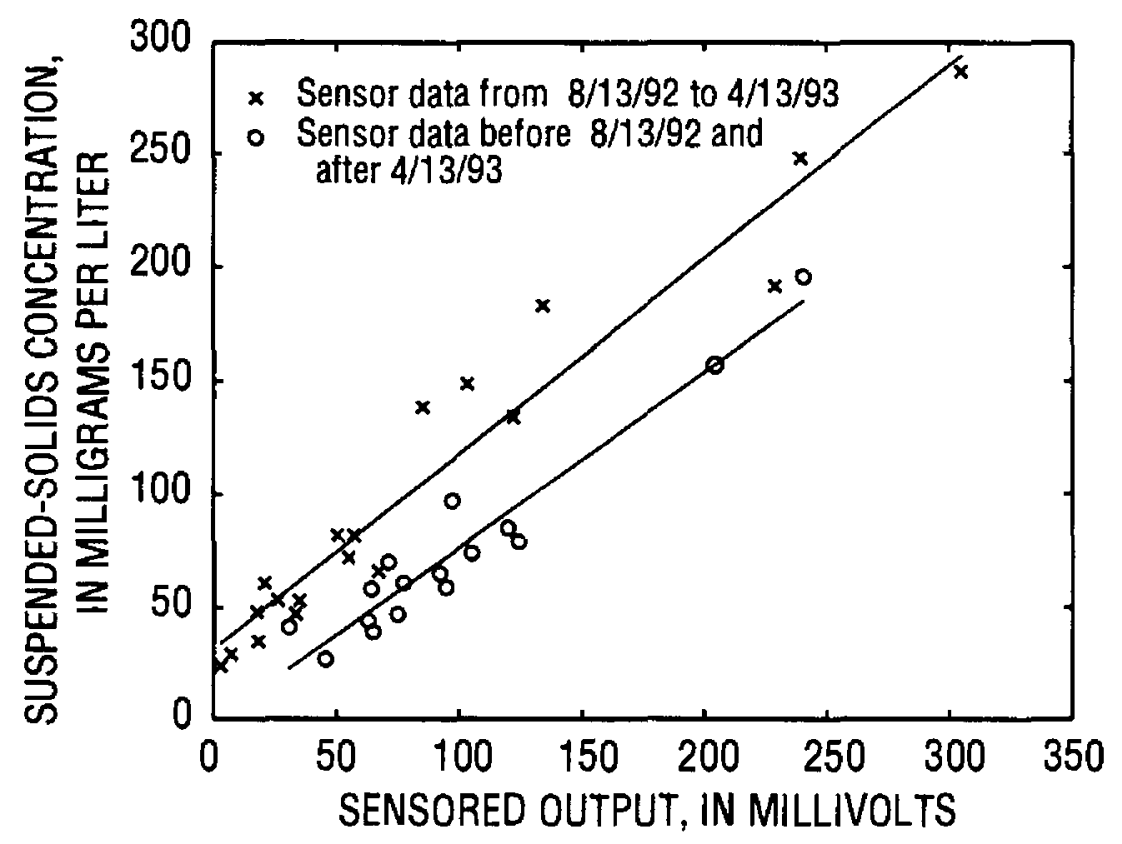

Figure 12. Calibration of near-bottom optical backscatterance sensor at channel marker 17 , South San Francisco Bay, California, water years 1992 and 1993.

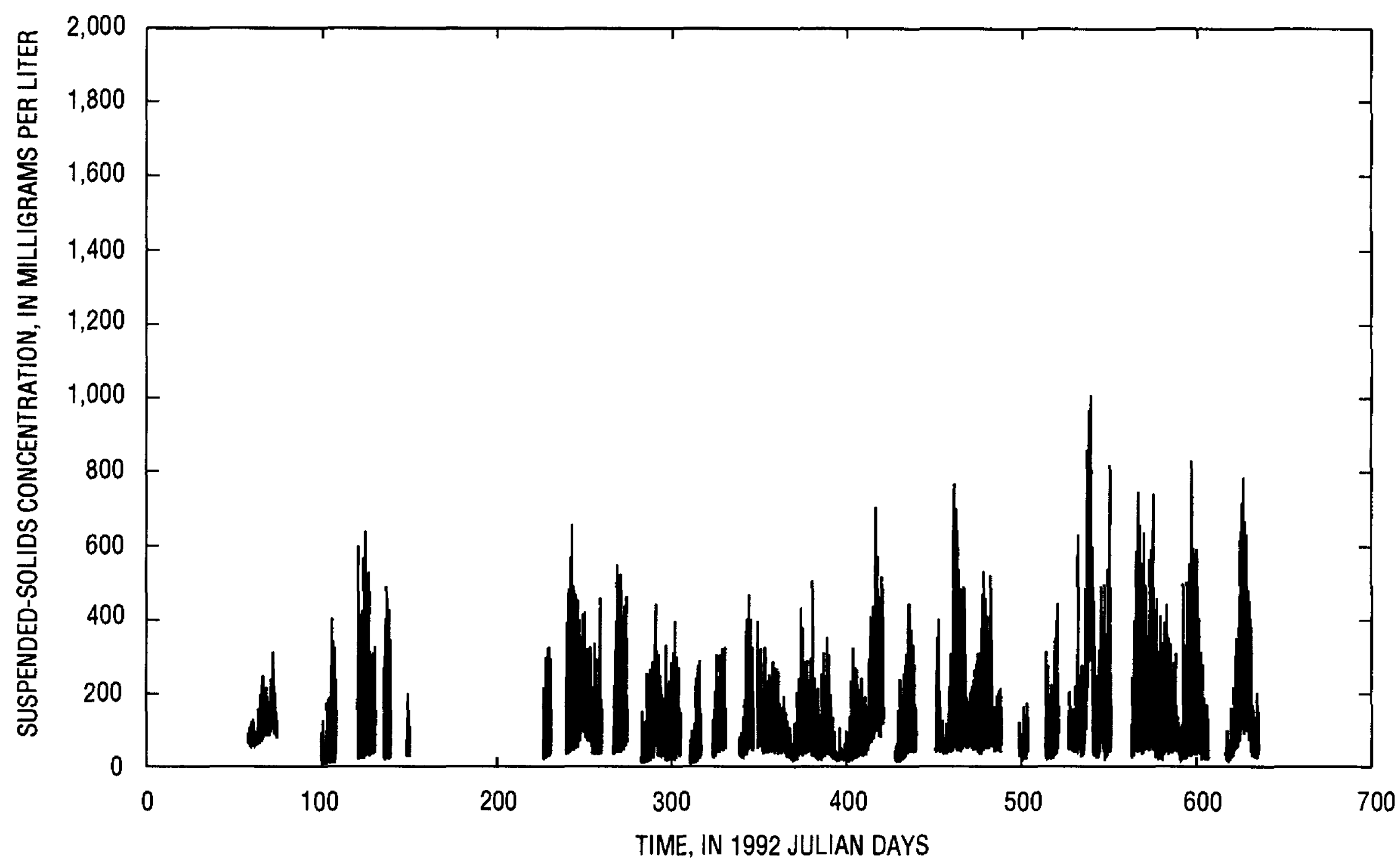

Figure 13. Time series of mid-depth suspended-solids concentration at channel marker 17, South San Francisco Bay, California, water years 1992 and 1993. 


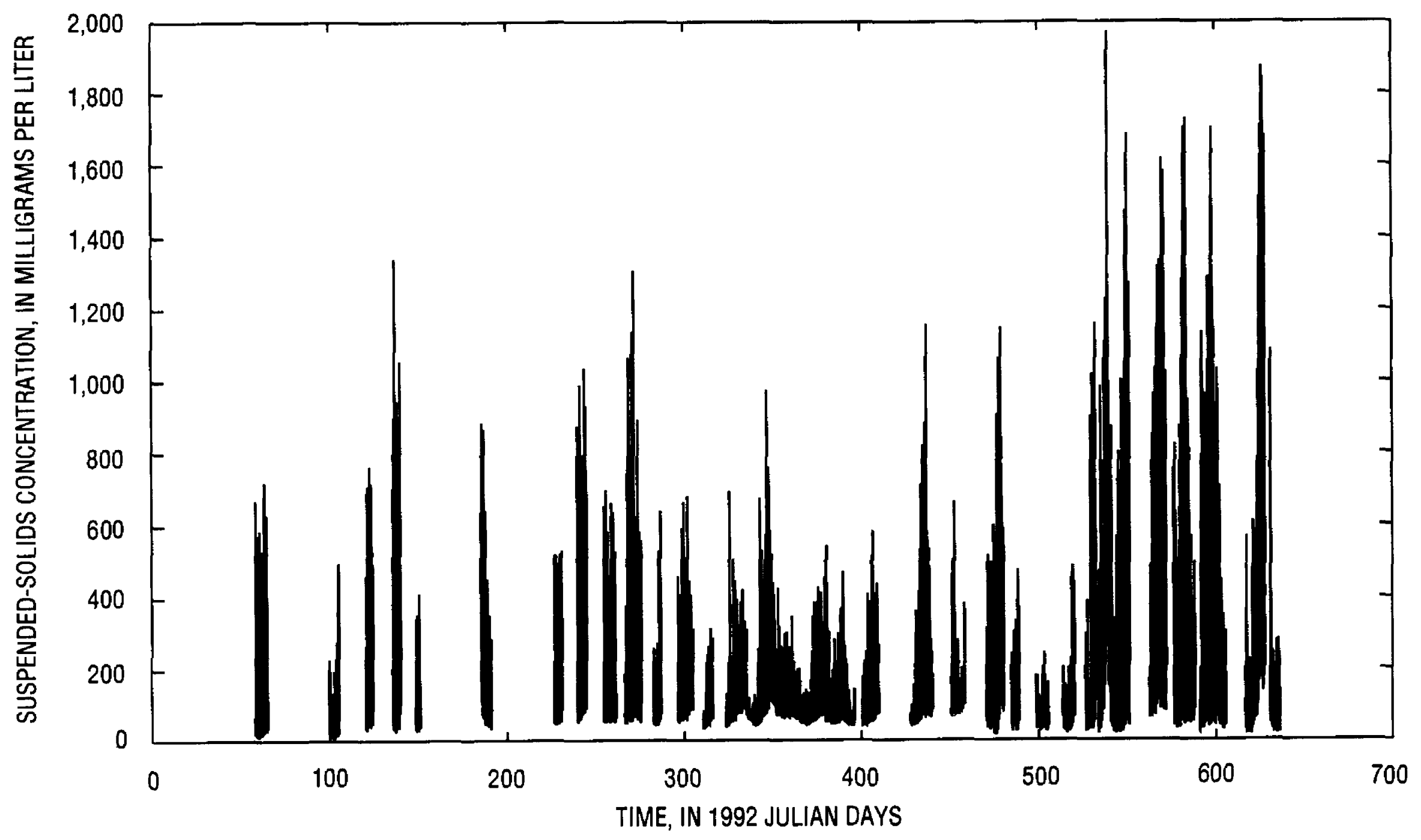

Figure 14. Time series of near-bottom suspended-solids concentration at channel marker 17, South San Francisco Bay, California, water years 1992 and 1993.

\section{Dumbarton Bridge}

The calibration of the mid-depth sensor at Dumbarton Bridge had a standard error of $14.5 \mathrm{mg} / \mathrm{L}$ (fig. 15 ), and the near-bottom sensor had a standard error of $20.4 \mathrm{mg} / \mathrm{L}$ (fig. 16). Suspended-solids concentration data collected at the Dumbarton Bridge during water years 1992 and 1993 are presented in figures 17 and 18 and a statistical summary is given in table 1 . The data collected by the mid-depth sensor were 38.3 percent valid, and the data collected by the nearbottom sensor were 51.3 percent valid.

\section{San Mateo Bridge}

Calibration of the mid-depth sensor at the San Mateo Bridge had a standard error of $10.7 \mathrm{mg} / \mathrm{L}$ (fig. 19). Three different sensors were used at the nearbottom position. The calibration of the first sensor, in operation from December 23, 1991, to September 22,1992 , had a standard error of $14.4 \mathrm{mg} / \mathrm{L}$ (fig. 20). The calibration of the second probe, in use from September 22, 1992, to November 4, 1992, had a standard error of $10.95 \mathrm{mg} / \mathrm{L}$ (fig. 20). Calibration of the third sensor, in use from November 4, 1992, to September 30,1993 , had a standard error of $14.3 \mathrm{mg} / \mathrm{L}$

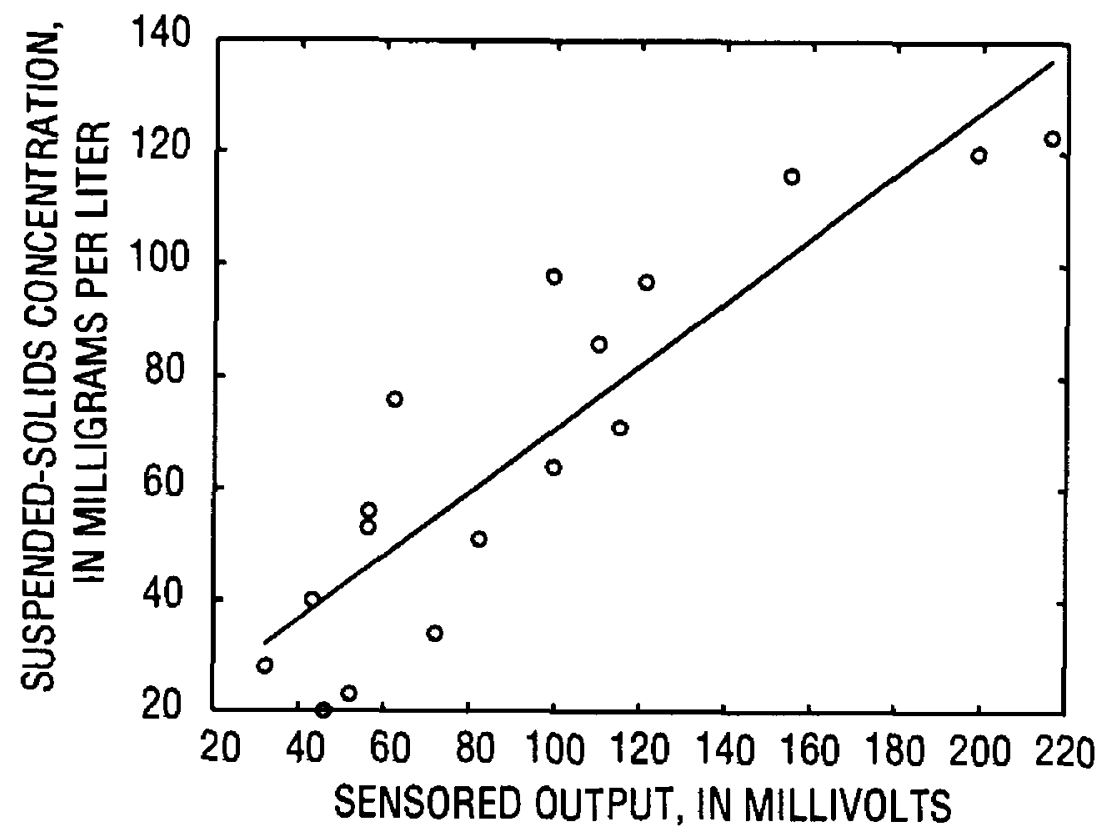

Figure 15. Calibration of mid-depth optical backscatterance sensor at Dumbarton Bridge, South San Francisco Bay, California, water year 1993.

(fig. 20). Suspended-solids concentration data collected during water years 1992 and 1993 are presented in figures 21 and 22 and a statistical summary is given in table 1. Data collected by the mid-depth sensor were 42.6 percent valid, and data collected by the near-bottom sensor were 46.0 percent valid. 


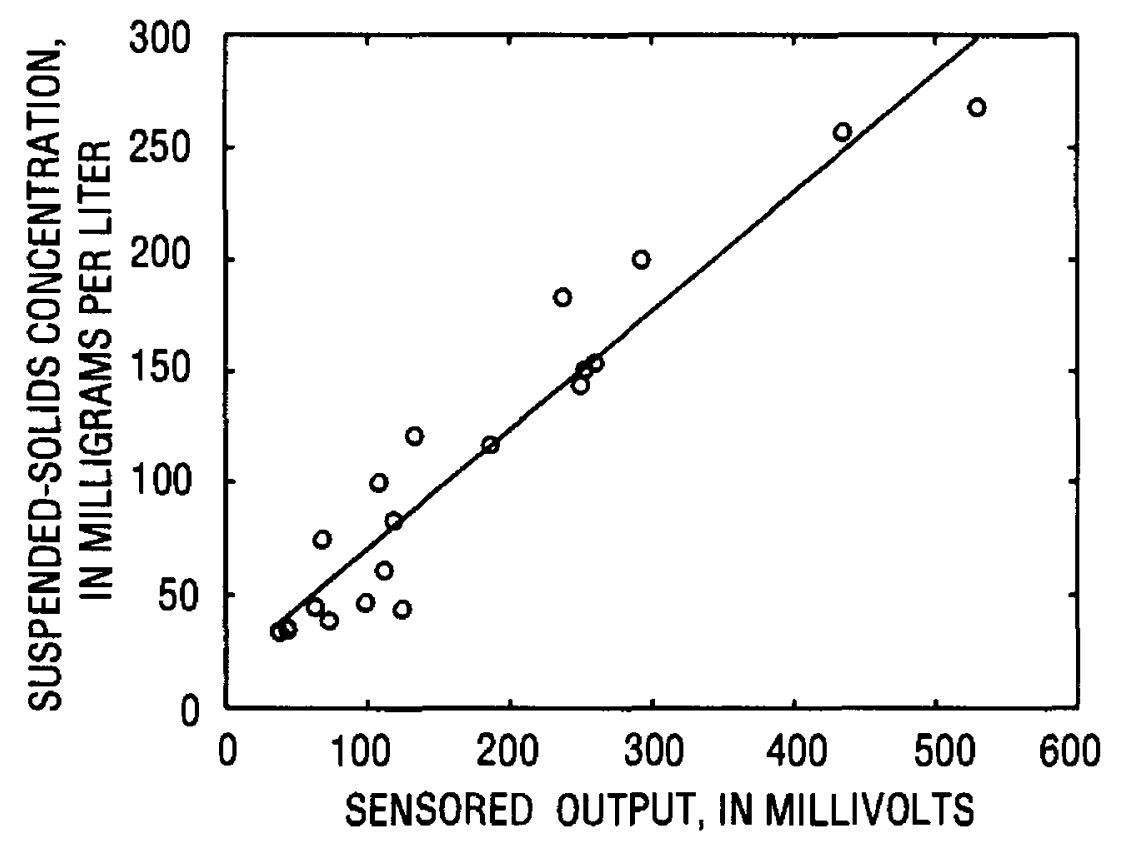

Figure 16. Calibration of near-bottom optical backscatterance sensor at Dumbarton Bridge, South San Francisco Bay, California, water year 1993.

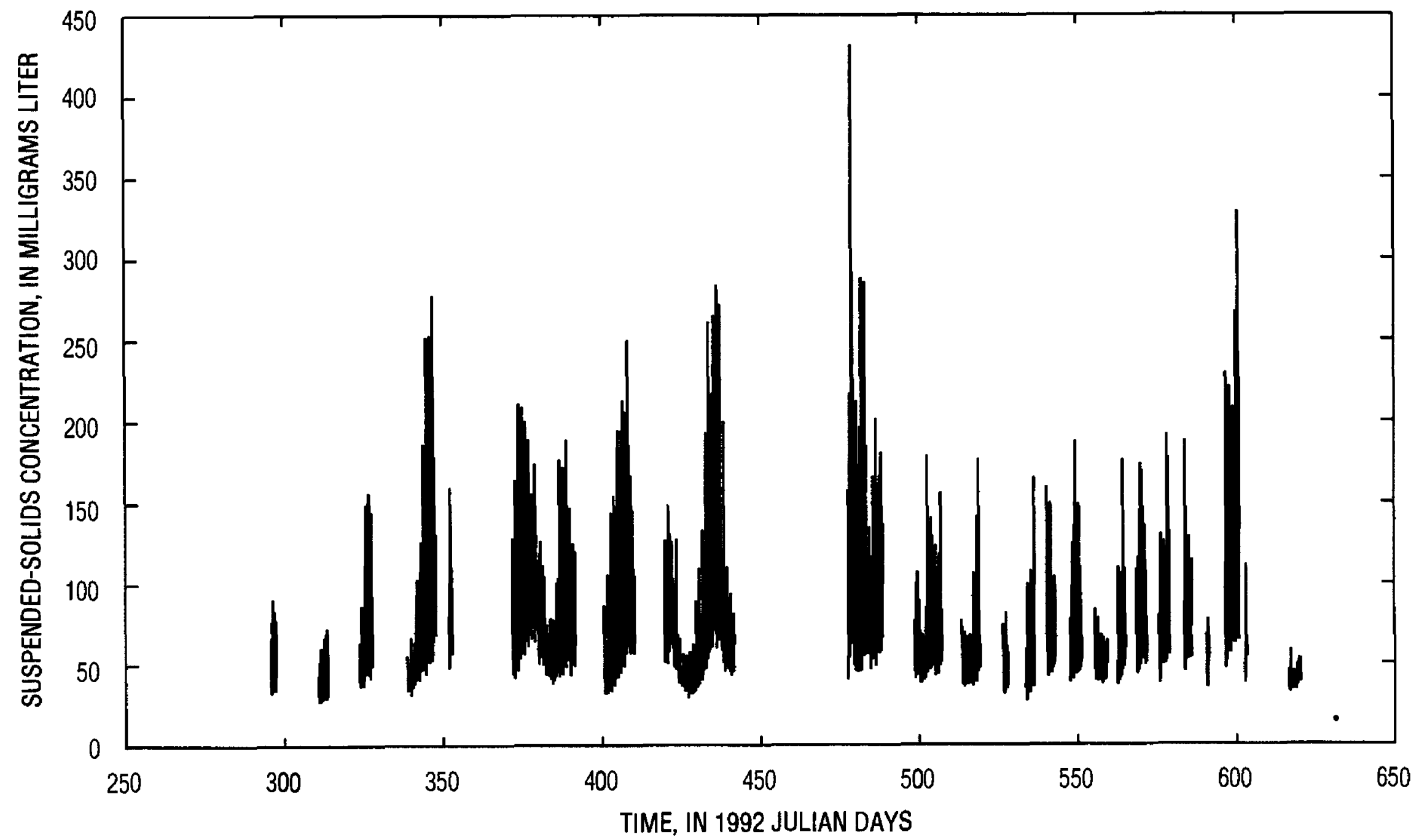

Figure 17. Time series of mid-depth suspended-solids concentration at Dumbarton Bridge, South San Francisco Bay, California, water year 1993. 


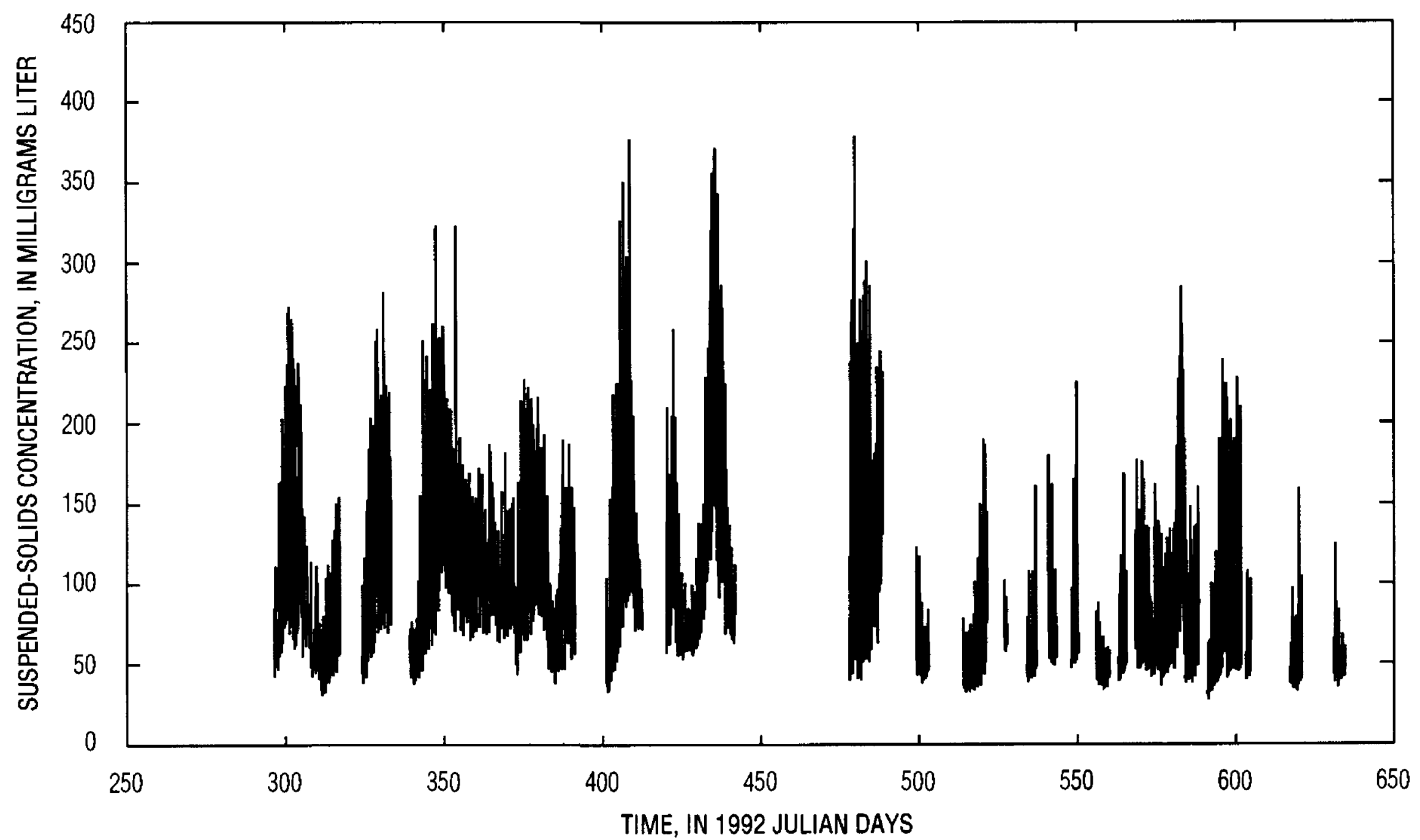

Figure 18. Time series of near-bottom suspended-solids concentration at Dumbarton Bridge, South San Francisco Bay, California, water year 1993.

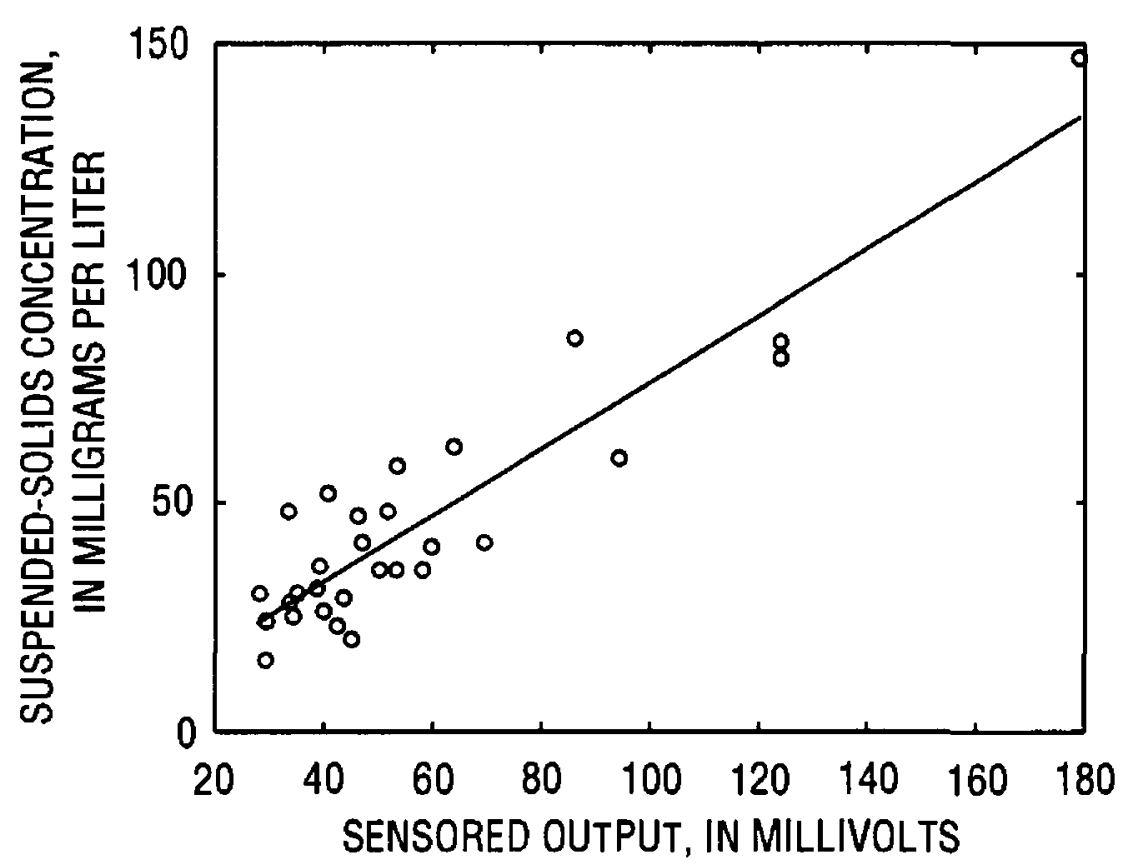

Figure 19. Calibration of mid-depth optical backscatterance sensor at San Mateo Bridge, South San Francisco Bay, California, water years 1992 and 1993.

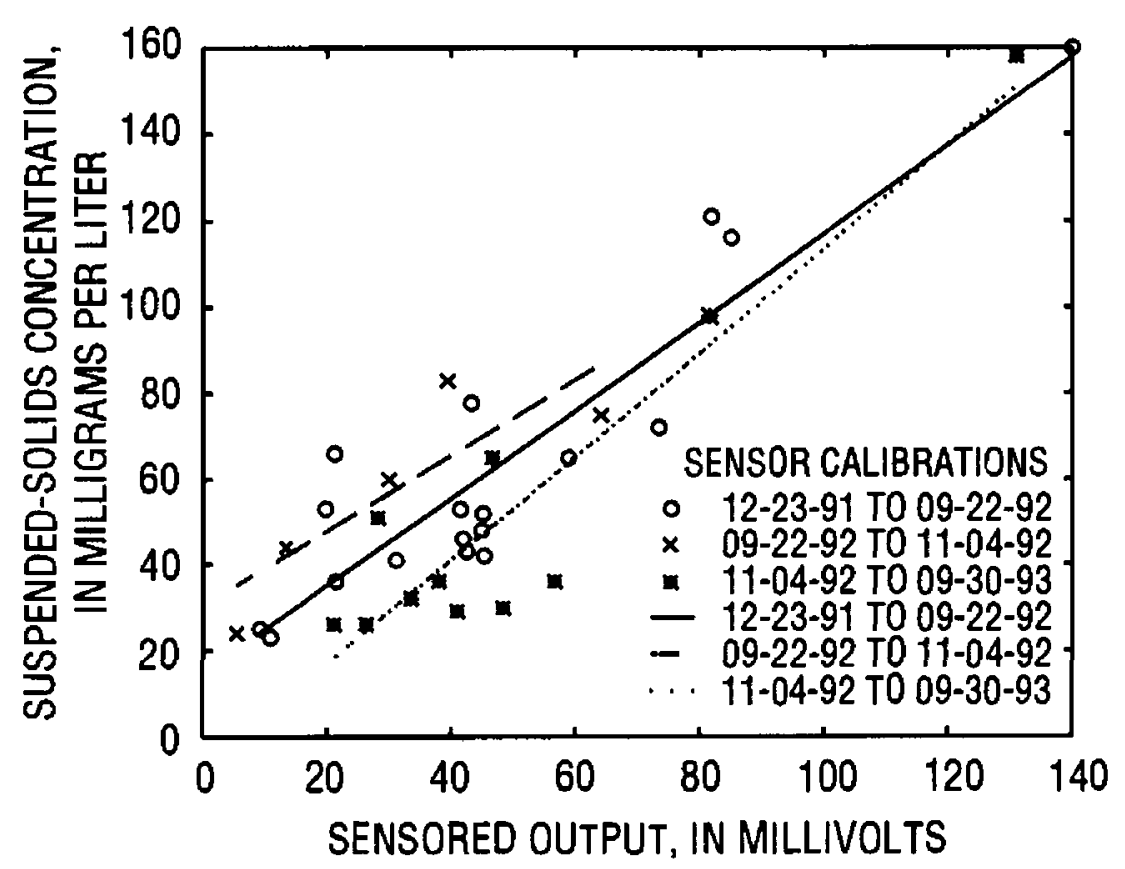

Figure 20. Calibration of near-bottom optical backscatterance sensor at San Mateo Bridge, South San Francisco Bay, California, water years 1992 and 1993. 


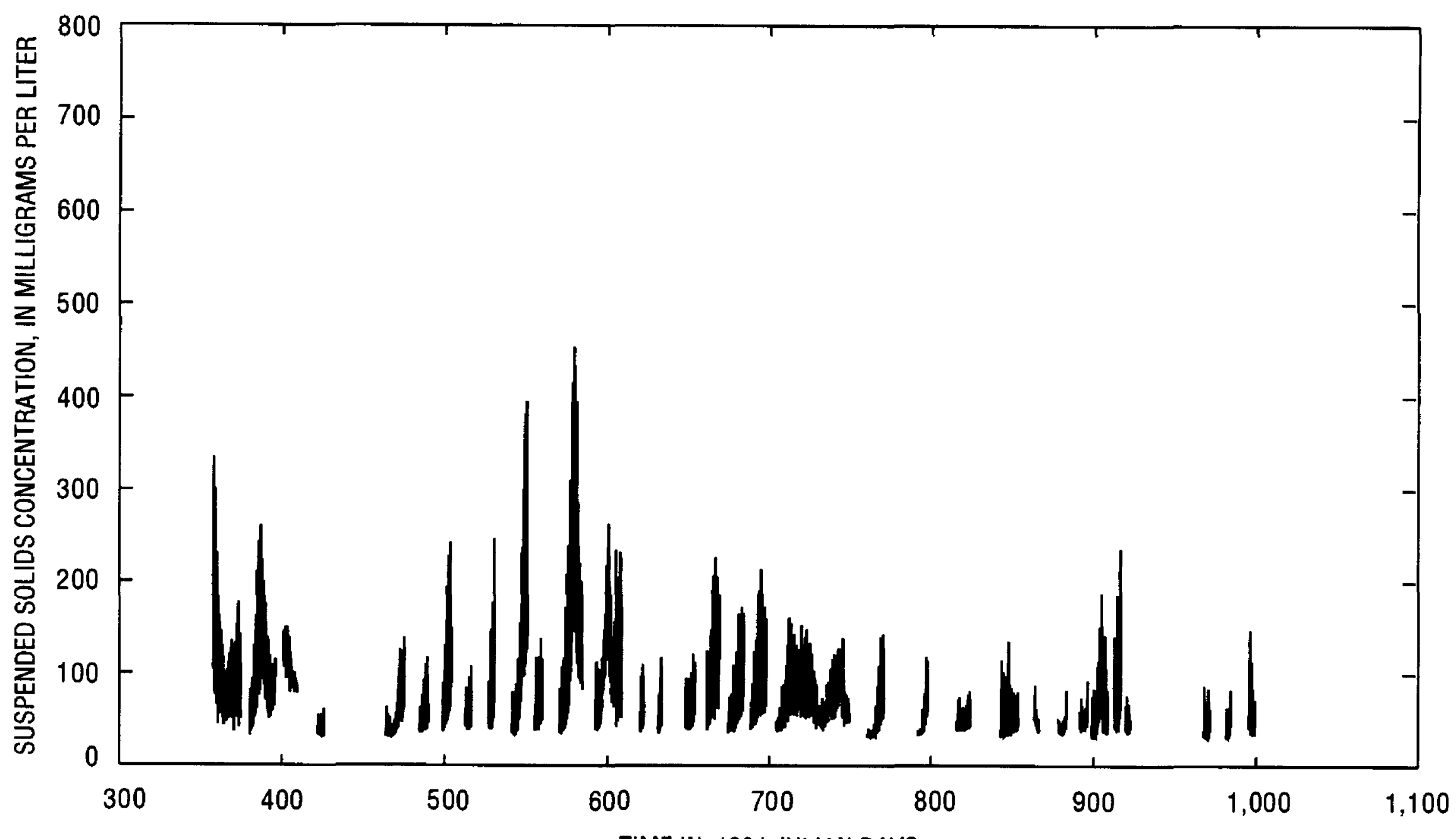

TIME IN, 1991 JULIAN DAYS

Figure 21. Time series of mid-depth suspended-solids concentration at San Mateo Bridge, South San Francisco Bay, California, water years 1992 and 1993.

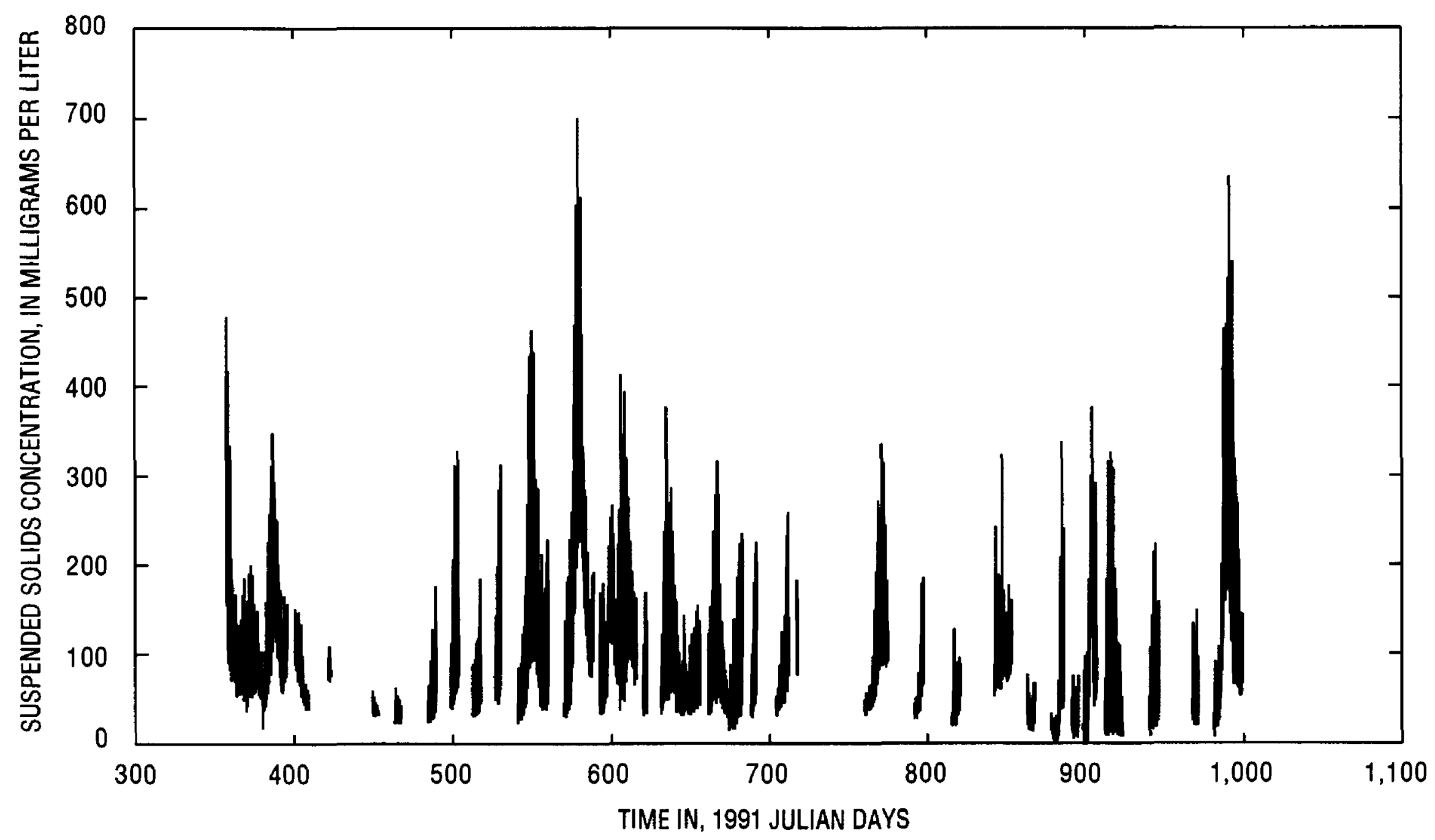

Figure 22. Time series of near-bottom suspended-solids concentration at San Mateo Bridge, South San Francisco Bay, California, water years 1992 and 1993. 


\section{SUMMARY}

Suspended-solids concentration data were collected by the U.S. Geological Survey at five sites in Central and South San Francisco Bays during water years 1992 and 1993. Optical backscatterance sensors controlled by an electronic data logger were used to monitor suspended solids. Water samples were collected to calibrate the electrical output of the optical backscatterance sensors to suspended-solids concentrations, and the optical backscatterance data were recovered and edited. Biological growth can foul optical backscatterance sensors and about half of the data was invalidated by fouling. Complete data are available from the files of the U.S. Geological Survey in Sacramento.

\section{References}

Carlson, P.R., and McCulloch, D.S., 1974, Aerial observations of suspended-sediment plumes in San Francisco Bay and the adjacent Pacific Ocean: Journal of U.S. Geological Survey Research, v. 2, no. 5, p. 519-526.

Cloern, J.E., 1987, Turbidity as a control on phytoplankton biomass and productivity in estuaries: Continental Shelf Research, v. 7, no. 11/12, p. 1367-1381.

Cole, B.E., and Cloern, J.E., 1987, An empirical model for estimating phytoplankton productivity in estuaries: Marine Ecology Progress Series, v. 36, p. 299-305.

Conomos, T.J., and Peterson, D.H., 1977, Suspended-particle transport and circulation in San Francisco Bay, an overview: Estuarine Processes, v. 2, p. 82-97.

Domagalski, J.L., and Kuivila, K.M., 1993, Distributions of pesticides and organic contaminants between water and suspended sediment, San Francisco Bay, California: Estuaries, v. 16, no. 3A, p. 416-426.

Downing, J.P., 1983, An optical instrument for monitoring suspended particulates in ocean and laboratory: Proceedings of OCEANS '83, August 29-September 1, 1983, San Francisco, p. 199-202.
Downing, J.P., Sternberg, R.W., and Lister, C.R.B., 1981, New instrumentation for the investigation of sediment suspension processes in the shallow marine environment: Marine Geology, v. 42, p. 19-34.

Fishman, M.J., and Friedman, L.C., 1989, Methods for determination of inorganic substances in water and fluvial sediments: U.S. Geological Survey Techniques of Water-Resources Investigations, book 5, ch. A1, $545 \mathrm{p}$.

Hammond, D.E., Fuller, C., Harmon, D., Hartman, B., Korosec, M., Miller, L.G., Rea, R., Warren, S., Berelson, W., and Hager, S.W., 1985, Benthic fluxes in San Francisco Bay: Hydrobiologia, v. 129, p. 69-90.

Kuwabara, J.S., Chang, C.C.Y., Cloern, J.E., Fries, T.L., Davis, J.A., and Luoma, S.N., 1989, Trace metal associations in the water column of South San Francisco Bay, California: Estuarine, Coastal and Shelf Science, v. 28, p. 307-325.

Levesque, V.A., and Schoellhamer, D.H., 1995, Summary of sediment resuspension monitoring activities, Old Tampa Bay and Hillsborough Bay, Florida, 1988-91: U.S. Geological Survey Water-Resources Investigations Report 94-4081, $31 \mathrm{p}$.

Luoma, S.N., Cain, D., and Johansson, C., 1985, Temporal fluctuations of silver, copper, and zinc in the bivalve Macoma balthica at five stations in South San Francisco Bay: Hydrobiologia, v. 129, p. 109-120.

Porterfield, George, 1980, Sediment transport of streams tributary to San Francisco, San Pablo, and Suisun Bays, California, 1909-1966: U.S. Geological Survey Water-Resources Investigations 80-64, $91 \mathrm{p}$.

Powell, T.M., Cloern, J.E., and Huzzey, L.M., 1989, Spatial and temporal variability in South San Francisco Bay (USA). I. Horizontal distributions of salinity, suspended sediments, and phytoplankton biomass and productivity: Estuarine, Coastal and Shelf Science, v. 28 , p. $583-597$.

Smith, L.H., 1987, A review of circulation and mixing studies of San Francisco Bay, California: U.S. Geological Survey Circular 1015, $38 \mathrm{p}$.

U.S. Environmental Protection Agency, 1992, State of the estuary: Dredging and waterway modification: U.S. Environmental Protection Agency San Francisco Estuary Project, ch. 8, p. 191-215. 